\title{
Cytosolic organelles shape calcium signals and exo-endocytotic responses of chromaffin cells
}

\author{
Antonio G. García a,b,c,*,1, Fernando Padín a,b,1, José C. Fernández-Morales a,b, \\ Marcos Maroto $^{\mathrm{a}, \mathrm{b}}$, Javier García-Sancho ${ }^{\mathrm{d}}$ \\ a Instituto Teófilo Hernando, Instituto de Investigaciones Sanitarias del Hospital de la Princesa, Facultad de Medicina, Universidad Autónoma de Madrid, Madrid, Spain

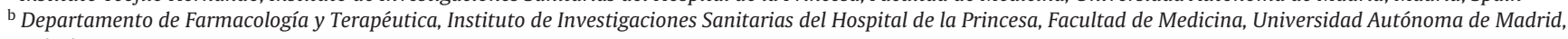 \\ Madrid, Spain \\ ' Servicio de Farmacología Clínica, Instituto de Investigaciones Sanitarias del Hospital de la Princesa, Facultad de Medicina, Universidad Autónoma de Madrid, Madrid, Spain \\ d Instituto de Biología y Genética Molecular (IBGM), Universidad de Valladolid and CSIC, c/Sanz y Forés, 3, 47003 Valladolid, Spain
}

\section{A R T I C L E I N F O}

\section{Article history:}

Received 13 October 2011

Received in revised form 2 December 2011

Accepted 5 December 2011

Available online 29 December 2011

\section{Keywords:}

Calcium tetrads

Chromaffin cells

Calcium signalling

Calcium microdomains

Exocytosis

Endocytosis

Mitochondria

Endoplasmic reticulum

$\mathrm{Ca}^{2+}$ cycling

\begin{abstract}
A B S T R A C T
The concept of stimulus-secretion coupling was born from experiments performed in chromaffin cells 50 years ago. Stimulation of these cells with acetylcholine enhances calcium $\left(\mathrm{Ca}^{2+}\right)$ entry and this generates a transient elevation of the cytosolic $\mathrm{Ca}^{2+}$ concentration $\left(\left[\mathrm{Ca}^{2+}\right]_{c}\right)$ that triggers the exocytotic release of catecholamines. The control of the $\left[\mathrm{Ca}^{2+}\right]_{c}$ signal is complex and depends on various classes of plasmalemmal calcium channels, cytosolic calcium buffers, the uptake and release of $\mathrm{Ca}^{2+}$ from cytoplasmic organelles, such as the endoplasmic reticulum, mitochondria, chromaffin vesicles and the nucleus, and $\mathrm{Ca}^{2+}$ extrusion mechanisms, such as the plasma membrane $\mathrm{Ca}^{2+}$-stimulated ATPase, and the $\mathrm{Na}^{+} / \mathrm{Ca}^{2+}$ exchanger. Computation of the rates of $\mathrm{Ca}^{2+}$ fluxes between the different cell compartments support the proposal that the chromaffin cell has developed functional calcium tetrads formed by calcium channels, cytosolic calcium buffers, the endoplasmic reticulum, and mitochondria nearby the exocytotic plasmalemmal sites. These tetrads shape the $\mathrm{Ca}^{2+}$ transients occurring during cell activation to regulate early and late steps of exocytosis, and the ensuing endocytotic responses. The different patterns of catecholamine secretion in response to stress may thus depend on such local $\left[\mathrm{Ca}^{2+}\right]_{\mathrm{c}}$ transients occurring at different cell compartments, and generated by redistribution and release of $\mathrm{Ca}^{2+}$ by cytoplasmic organelles. In this manner, the calcium tetrads serve to couple the variable energy demands due to exo-endocytotic activities with energy production and protein synthesis.
\end{abstract}

(C) 2011 Elsevier Ltd. All rights reserved.

\section{Introduction}

Stressful conflicts trigger a surge of the catecholamines adrenaline and noradrenaline that mobilize the body to survive by combating an enemy or to flee from danger, the so-called "fight or flight" response. This response is the end result of a secretory event that takes place in the adrenal medulla, the inner part of the two adrenal glands located just above the kidneys. The adrenal medulla is composed of chromaffin cells that secrete adrenaline and noradrenaline. These cells are of interest not only to explore the mechanisms underlying the "fight or flight" response, but also because they have been used for decades as excellent models to study the working of other secretory cells, in particular neurons.

\footnotetext{
* Corresponding author at: Instituto Teófilo Hernando, Facultad de Medicina, Universidad Autónoma de Madrid, C/Arzobispo Morcillo, 4, 28029 Madrid, Spain. Tel.: +34 914973120 .

E-mail address: agg@uam.es (A.G. García).

1 Equal contributors.
}

Acetylcholine, the physiological neurotransmitter at the splanchnic nerve-chromaffin cell synapse [1], causes the release of catecholamines from the adrenal gland. This secretory response is suppressed in the absence of extracellular calcium $\left(\mathrm{Ca}^{2+}\right)[2]$. Also, acetylcholine enhances $\mathrm{Ca}^{2+}$ entry into adrenal medullary chromaffin cells [3]. On the basis of these and other pioneering experiments William W. Douglas coined the expression "stimulus-secretion coupling" as the basic mechanism involved in neurotransmitter and hormone secretion; $\mathrm{Ca}^{2+}$ was the coupling ion between the stimulus and the exocytotic response [4]. Since then, adrenal chromaffin cells from various mammalian species but mostly from bovine, rats and mice have extensively been used to study the relationship between the changes of cytosolic concentrations of free $\mathrm{Ca}^{2+}$ ions in the cytosol $\left(\left[\mathrm{Ca}^{2+}\right]_{\mathrm{c}}\right)$, its redistribution into organelles, its clearance from the cytosol and the exocytotic and endocytotic responses triggered by acetylcholine and other nicotinic and muscarinic receptor agonists, various agonists for G-protein coupled receptors and different depolarising stimuli including high concentrations of potassium $\left(\mathrm{K}^{+}\right)$, square depolarising pulses or action potentials. 
Chromaffin cells are excitable cells and fire action potentials that open various of the neuronal-type voltage-dependent calcium channels (VDCCs) and produce $\mathrm{Ca}^{2+}$ entry; the resulting $\left[\mathrm{Ca}^{2+}\right]_{\mathrm{c}}$ signal triggers exocytosis. Because cytoplasmic organelles can take up and release $\mathrm{Ca}^{2+}$ to the cytosol, understanding the $\left[\mathrm{Ca}^{2+}\right]_{\mathrm{c}}$ signal requires understanding of the $\mathrm{Ca}^{2+}$ redistribution between the cytosol and the different organelles. The coding of the photoprotein aequorin gene [5] made it possible to introduce targeting sequences, and measuring selective $\left[\mathrm{Ca}^{2+}\right]$ changes in different organelles [6]. This methodology has been applied during the last decade to gain insight into the role of organelles in shaping $\left[\mathrm{Ca}^{2+}\right]_{\mathrm{c}}$ signalling and exocytosis in chromaffin cells. This review focuses on the pathways for $\mathrm{Ca}^{2+}$ entry into the chromaffin cell, on the intracellular organelles that contribute to the redistribution of the $\mathrm{Ca}^{2+}$ entering the cell, and on the mechanisms that terminate the $\left[\mathrm{Ca}^{2+}\right]_{c}$ signals and extrude the cation outside the cell. We also analyse the influence of this $\mathrm{Ca}^{2+}$ trafficking between the different organelles on the exocytotic responses. Finally, we analyse the kinetics of $\mathrm{Ca}^{2+}$ handling at different cell compartments, trying to obtain a unified picture of $\mathrm{Ca}^{2+}$ handling and the exo-endocytotic responses of chromaffin cells. Several reviews of some of these questions have been published [7-11].

\section{Calcium influx}

The most relevant $\mathrm{Ca}^{2+}$ entry pathways in chromaffin cells are VDCCs, store-operated $\mathrm{Ca}^{2+}$ channels (SOCCs) and ligand-gated calcium channels. The characteristics and regulation of the various VDCC subtypes will extensively be described by E. Carbone in this special number of Cell Calcium. So, we will only make a brief mention to them.

\subsection{Voltage-dependent calcium channels}

As in neurons [12], multiple VDCCs are expressed in chromaffin cells [13]. Significant differences exist in the densities of each channel subtype in cells from different species. For instance, $L$ channels $\left(\alpha_{1 \mathrm{D}}\right.$, Cav1.3) carry near $50 \%$ of the whole-cell current in cat, rat and mouse chromaffin cells. In contrast, $\mathrm{P} / \mathrm{Q}$ channels $\left(\alpha_{1 \mathrm{~A}}\right.$, Cav2.1) account for $50-60 \%$ of the current in bovine and human chromaffin cells. $\mathrm{N}$-type channels ( $\alpha_{1 \mathrm{~B}}$, Cav2.2) contribute $80 \%$ in pig, $45 \%$ in cat and $30 \%$ in bovine, rat, mouse and human chromaffin cells. Finally, R-type channels ( $\alpha_{1 \mathrm{E}}$, Cav2.3) are present only in mouse chromaffin cells [9].

\subsection{Store-operated calcium channels}

In many non-excitable cells, inositol 1,4,5-trisphosphate ( $\operatorname{InsP}_{3}$ ) generated by agonist stimulation causes a biphasic elevation of $\left[\mathrm{Ca}^{2+}\right]_{\mathrm{c}}$. The initial peak is due to $\mathrm{ER} \mathrm{Ca}^{2+}$ release via the $\mathrm{InsP}_{3}$ receptor channel while the subsequent maintained plateau phase is associated to $\mathrm{Ca}^{2+}$ entry through SOCCs [14-16]. The plateau phase is produced by a small-conductance, voltage-independent $\mathrm{Ca}^{2+}$ release activated $\mathrm{Ca}^{2+}$ current $\left(I_{\mathrm{CRAC}}\right)$, that serves to replenish the $\mathrm{Ca}^{2+}$ store [17-19]. Having multiple types of VDCCs, excitable cells could be refilling their depleted $\mathrm{ER} \mathrm{Ca}^{2+}$ store by $\mathrm{Ca}^{2+}$ entering through those high-conductance channels. This has been shown to apply for some neurosecretory cells [20,21] including bovine chromaffin cells; in these cells loaded with ER-targeted aequorin, high $\mathrm{K}^{+}$accelerates the ER $\mathrm{Ca}^{2+}$ store refilling upon $\mathrm{Ca}^{2+}$ reintroduction [22].

Early experiments demonstrated $\mathrm{Ca}^{2+}$ influx through SOCCs upon ER $\mathrm{Ca}^{2+}$ depletion of bovine chromaffin cells [23]; this was corroborated by later experiments [22,24-28]. A direct proof for the presence of SOCCs was obtained from voltage-clamped bovine chromaffin cells where a small-amplitude, voltage-independent
$I_{\text {CRAC }}$ carried by $\mathrm{Ca}^{2+}$ and $\mathrm{Na}^{+}$, was characterised under conditions of $\mathrm{Ca}^{2+}$ store depletion [29]. A $\mathrm{Ca}^{2+}$ entry pathway triggered by histamine and independent of the $\mathrm{ER} \mathrm{Ca}^{2+}$ store is also present in these cells $[25,30]$.

A few studies have explored the role of $\mathrm{Ca}^{2+}$ entry through SOCCs in triggering exocytosis in bovine chromaffin cells. Thus, histamine and angiotensin II stimulate exocytosis by a combination of $\mathrm{ER} \mathrm{Ca}^{2+}$ release and additional $\mathrm{Ca}^{2+}$ entry through SOCCs [24]. More convincing evidence arises from experiments performed in voltage-clamped cells, where angiotensin II-induced exocytosis was associated with an uncharacterised leak current [27]. In addition, exocytosis could be elicited in the absence of depolarisation by photolysis of caged InsP $\mathrm{P}_{3}$ [31] or by bradykinin [32]. But the most convincing evidence comes from experiments done with stimulation of $\mathrm{Ca}^{2+}$ entry through SOCCs by store depletion that produces exocytosis at negative membrane potentials that maintain closed the VDCCs [29].

Why a bovine chromaffin cell expressing $\mathrm{L}, \mathrm{N}$ and $\mathrm{P} / \mathrm{Q}$ highconductance VDCCs [9] should still require additional pathways for $\mathrm{Ca}^{2+}$ entry is puzzling. The fact such pathways can be physiologically activated by action potentials or sustained depolarisation triggered by acetylcholine is even more puzzling. Combining aequorins and confocal microscopy, $\mathrm{Ca}^{2+}$-induced $\mathrm{Ca}^{2+}$ release (CICR) was shown to be activated by $\mathrm{K}^{+}$or 50 -ms depolarising pulses in bovine chromaffin cells [22]. Upon repetitive stimulation with bursts of action potentials under stress, CICR may produce partial $\mathrm{ER} \mathrm{Ca}^{2+}$ depletion and give rise to SOCC activation. A modulatory role of this capacitative $\mathrm{Ca}^{2+}$ entry on exocytosis in chromaffin cells has been suggested, but other pathways for $\mathrm{Ca}^{2+}$ entry were not under control in these experiments [26]. Later, direct experiments demonstrated that receptor-free activation of $\mathrm{Ca}^{2+}$ entry via SOCCs is sufficient to trigger and or facilitate exocytosis in these cells [29]. In this context, it is interesting that hyperpolarisation is associated with histamine receptor stimulation that is coupled to $\mathrm{ER} \mathrm{Ca}^{2+}$ release and activation of small-conductance $\mathrm{Ca}^{2+}$-activated $\mathrm{K}^{+}$channels [33]. This mechanism could amplify $\mathrm{Ca}^{2+}$ influx via SOCCs, thus facilitating the exocytosis triggered by bursts of action potentials, in a kind of long-lasting modulatory mechanism for stimulus-secretion coupling.

\subsection{Ligand-gated calcium channels}

Nicotinic receptors for acetylcholine (nAChRs), as well as receptors for glutamate and ATP, underlie excitatory transmission at central and peripheral synapses. These receptors are ion channels permeable to cations. The fraction of the inward cation current carried by $\mathrm{Ca}^{2+}$, triggered by agonists in various cell types is about $5 \%$ for nAChRs and ATP receptors and around 10\% for N-methylD-aspartate (NMDA) receptors [34,35]. In bovine chromaffin cells the fraction of acetylcholine-elicited inward current carried by $\mathrm{Ca}^{2+}$ accounts for about 5\% [36]. $\mathrm{Ca}^{2+}$ entering through nAChRs may contribute to augment vesicle movement and the size of the ready-release vesicle pool $[37,38]$. Furthermore, glutamate receptors seem to mediate an increase of $\left[\mathrm{Ca}^{2+}\right]_{\mathrm{c}}$ and exocytosis in bovine chromaffin cells [39]. On the other hand, various purinoceptor subtypes that respond to ATP with a $\left[\mathrm{Ca}^{2+}\right]_{\mathrm{c}}$ increase have also been found in these cells [40]. Remarkable differences among species have been found. For instance, rat chromaffin cells lack P2X receptors while in the guinea-pig, ATP generates an inward current that seems to be associated to $\mathrm{P} 2 \mathrm{X}_{2}$ receptors [41]. $\mathrm{Na}^{+}$influx through P2X channels causes depolarisation of bovine chromaffin cells, enhances $\mathrm{Ca}^{2+}$ entry through VDCCs and catecholamine release [42]. On the other hand, P2X receptors seem to be preferentially expressed by noradrenergic cells, while adrenergic cells preferentially contain P2Y metabotropic receptors [43]. These latter 
receptors exert an autocrine regulatory inhibition of inward $\mathrm{Ca}^{2+}$ currents through VDCCs of bovine cells $[44,45]$.

$\mathrm{GABA}_{\mathrm{A}}$ receptor agonists also cause cell depolarisation, an elevation of $\left[\mathrm{Ca}^{2+}\right]_{c}$, likely due to opening of VDCCs and the release of catecholamines [46-48]. Furthermore, GABA enhances the $\left[\mathrm{Ca}^{2+}\right]_{\mathrm{c}}$ elevation elicited by low-frequency electrical field stimulation of perfused rat adrenals [49]. It is still unclear how GABA can exert those modulatory effects; a paracrine role has been suggested for GABA co-stored and co-released with catecholamines during electrical stimulation of the splanchnic nerves at the adrenal medulla [49].

\section{Calcium redistribution}

The abrupt $\left[\mathrm{Ca}^{2+}\right]_{\mathrm{c}}$ transient generated by depolarising stimuli elicited by either action potentials or sustained depolarisations, are controlled not only by the different subtypes of VDCCs expressed by chromaffin cells, but also by cytosolic calcium buffers, $\mathrm{Ca}^{2+}$ sequestration or release by cytoplasmic organelles and extrusion by plasmalemmal calcium transporters. We will separately analyse these calcium regulatory elements (Fig. 1).

\subsection{Cytosolic calcium buffers}

$\mathrm{Ca}^{2+}$ buffering and diffusion in bovine chromaffin cells has been studied extensively by Neher and coworkers (see Section 5). However, the molecular nature of the cytosolic calcium buffers is unknown. Only a few reports have been devoted to the study of calcium-binding proteins in chromaffin cells. For instance, in

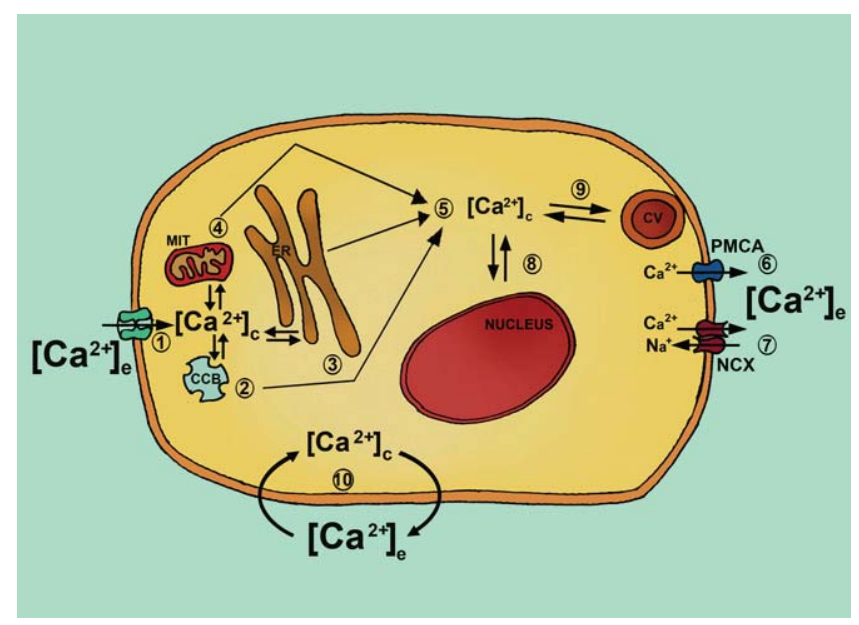

Fig. 1. Calcium $\left(\mathrm{Ca}^{2+}\right)$ cycling in the chromaffin cell. Upon cell depolarisation, extracellular $\mathrm{Ca}^{2+}$ enters the cell through voltage-dependent $\mathrm{Ca}^{2+}$ channels $(1, \mathrm{VDCCs})$. This generates a local cytosolic $\mathrm{Ca}^{2+}$ transient $\left(\left[\mathrm{Ca}^{2+}\right]_{\mathrm{c}}\right)$, with activation and clearance phases exhibiting spatial and temporal patterns that are tightly regulated by nearby poorly defined immobile cytosolic calcium buffers $(2, \mathrm{CCB})$, the endoplasmic reticulum (3, ER) and the mitochondrion (4, MIT). $\mathrm{Ca}^{2+}$ taken up by organelles and cytosolic calcium buffers is released back into the cytosol allowing its redistribution towards the cell core (5). Finally, to re-establish the cell $\mathrm{Ca}^{2+}$ balance, the plasmalemmal $\mathrm{Ca}^{2+}$ pump (6, PMCA) and $\mathrm{Na}^{2+} / \mathrm{Ca}^{2+}$ exchanger NCX (7) drive $\mathrm{Ca}^{2+}$ efflux back to the extracellular space. The nucleus (8) and chromaffin vesicles $(9, \mathrm{CV})$ may also contribute to $\mathrm{Ca}^{2+}$ redistribution. Pathways for $\mathrm{Ca}^{2+}$ entry other than VDCCs, such as store-operated calcium channels (SOCCs), nicotinic acetylcholine receptors, purinergic receptors, GABA and glutamate receptors have also been reported to be present in chromaffin cells; they are not represented for the sake of simplicity. Being an excitable cell driven by the sympathetic nervous system, the $\mathrm{Ca}^{2+}$ cycling must be continuously going on in the intact adrenal medullary tissue. The velocity of such $\mathrm{Ca}^{2+}$ cycling (10), depends on the rate of action potential firing and the sympathetic cholinergic input at different stress situations. Such variations in the velocity of $\mathrm{Ca}^{2+}$ cycling serve to adapt the bioenergetic needs of the cell, in order to secure the rapid release of catecholamines into the circulation, to prepare the body for the fight or flight response. bovine cells parvalbumin contains $\mathrm{Ca}^{2+} / \mathrm{Mg}^{2+}$ mixed sites that show slow $\mathrm{Ca}^{2+}$-binding kinetics under physiological conditions. Parvalbumin acts as a $\mathrm{Ca}^{2+}$ source during relaxation of $\left[\mathrm{Ca}^{2+}\right]_{c}$ peaks and extends the $\left[\mathrm{Ca}^{2+}\right]_{c}$ transient by conversion of a monoexponential decay in a biexponential one [50]. Another study reported that calbindin-D28k is homogeneously distributed in the cytosol of bovine cells while its distribution was preferentially concentrated at submembrane sites in mouse cells. The clearance of the $\mathrm{K}^{+}$-evoked $\left[\mathrm{Ca}^{2+}\right]_{c}$ transients was slower in bovine cells, but the initial quantal secretory response was faster in mouse chromaffin cells. Thus, the different distribution of calbindin-D28k does certainly affect $\mathrm{Ca}^{2+}$ signalling and exocytosis in both cell types [51].

\subsection{Nucleus}

$\mathrm{Ca}^{2+}$ has relevant functions in the regulation of gene expression in the nucleus. In addition, a few studies have approached the nuclear $\mathrm{Ca}^{2+}$ kinetics [52]. For instance, there is consensus that the nuclear envelope may somewhat delay the propagation of $\mathrm{Ca}^{2+}$ waves from the cytosol to the nucleus [53-55]. In PC12 and other cell types, half-equilibrium times for $\mathrm{Ca}^{2+}$ fluxes through the nuclear envelope are in the range of seconds [54]. Under these conditions, strong stimuli such as $\mathrm{K}^{+}$depolarisation or stimulation with UTP or bradykinin generate $\mathrm{Ca}^{2+}$ signals that are quickly transmitted to the nucleus. On the contrary, the progression of high-frequency $\left[\mathrm{Ca}^{2+}\right]_{c}$ oscillations to the nucleus may be dampened by the nuclear envelope [54]. The nuclear matrix also differ from the cytosol in having a larger $\mathrm{Ca}^{2+}$-buffering capacity [56], which would also result in an obvious slowing in the progression of the $\mathrm{Ca}^{2+}$ wave. It is interesting to note that selective nuclear signalling might be achieved by $\mathrm{Ca}^{2+}$ release from nuclear stores in certain cells [57].

\subsection{Chromaffin vesicles}

Chromaffin vesicles of bovine chromaffin cells contain as much as $40 \mathrm{mM}$ calcium [58]. Most of this calcium ( $>99.9 \%$ ) is bound to chromogranins and the free $\mathrm{Ca}^{2+}$ concentration is about $40 \mu \mathrm{M}$ $[59,60]$. At pH 7.5, chromogranin A binds $32 \mathrm{~mol}$ of $\mathrm{Ca}^{2+} / \mathrm{mol}$ protein, with a $K_{\mathrm{D}}$ of $4 \mathrm{mM}$; the binding capacity increases to $55 \mathrm{~mol}$ of $\mathrm{Ca}^{2+} /$ mol protein with a $K_{\mathrm{D}}$ of $2.7 \mathrm{mM}$ at the intravesicular $\mathrm{pH}$ of 5.5 [61]. Thus, an increase of intravesicular $\mathrm{pH}$ increases the free $\mathrm{Ca}^{2+}$ concentration, thereby facilitating its release into the cytosol. This has been experimentally demonstrated with alkalinising agents and protonophores, which enhance vesicular $\mathrm{Ca}^{2+}$ release, vesicle motion and exocytosis [62-66]. As much as $20-30 \%$ of the basal chromaffin cells volume is occupied by about 20,000 chromaffin vesicles [67] that store around $60 \%$ of total cell $\mathrm{Ca}^{2+}[59,68]$; however, scarce data are available to support the original hypothesis stating that intravesicular $\mathrm{Ca}^{2+}$ could be involved in the exocytotic process [69]. Experiments with alkalinising agents are certainly interesting; but it is difficult to envision the physiological context that they could mimic. The presence of InsP $_{3}$ receptors in the chromaffin vesicle membrane $[70,71]$ and InsP $_{3}$-induced vesicular $\mathrm{Ca}^{2+}$ release $[60,72,73]$ suggest that the $\mathrm{InsP}_{3}$ pathway may be physiologically relevant. It seems likely that vesicular $\mathrm{Ca}^{2+}$ release could be involved in slow pre-exocytotic steps aimed at mobilizing vesicles from a reserve pool to a ready-releasable pool, as it is the case for $\mathrm{Ca}^{2+}$ release from the ER (see Section 3.4). However, it is unlikely that this slow $\mathrm{Ca}^{2+}$ release can compete with the rapid high- $\mathrm{Ca}^{2+}$ microdomains (HCMDs) formed at subplasmalemmal exocytotic sites nearby VDCCs and docked vesicles ready to undergo fast exocytosis. Experimental protocols and techniques capable of distinguishing the various $\mathrm{Ca}^{2+}$ sources contributing 
to such HCMDs may enlighten the contribution of vesicular $\mathrm{Ca}^{2+}$ release in the various steps of exocytosis. For further analysis of this topic, see two recent reviews $[74,75]$.

\subsection{Endoplasmic reticulum}

Earlier observations established that $\mathrm{Ca}^{2+}$ uptake occurred in the sarcoplasmic reticulum of skeletal muscle $[76,77]$ through a $\mathrm{Mg}^{2+}$ - and ATP-dependent P-type transport $\mathrm{Ca}^{2+}$ ATPase, the sarcoendoplasmic reticulum $\mathrm{Ca}^{2+}$-ATPase (SERCA) [78]. This led to the concept of intracellular calcium stores that was soon extended to most nonexcitable and excitable cells including neurons and neurosecretory cells [79]. Two channels are mainly responsible for the release of $\mathrm{Ca}^{2+}$ from the ER store namely, the $\mathrm{InsP}_{3}$ receptor channel, which is activated by the $\mathrm{InsP}_{3}$ generated as a result of G-protein coupled membrane receptor activation, and the ryanodine receptor channel (RyR) that is activated by enhanced $\left[\mathrm{Ca}^{2+}\right]_{c}$, caffeine and ryanodine. $\mathrm{Ca}^{2+}$ binding to RyR opens the channel, thereby triggering the release of $\mathrm{Ca}^{2+}$ into the cytosol through the $\mathrm{Ca}^{2+}$-induced $\mathrm{Ca}^{2+}$ release mechanism (CICR).

Considerable efforts have been devoted to clarify the kinetics of $\mathrm{Ca}^{2+}$ fluxes of the ER $\mathrm{Ca}^{2+}$ store, and its role in controlling preexocytotic and the last exocytotic steps in chromaffin cells. For instance, histamine, angiotensin II, bradykinin and carbachol have been shown to augment the production of $\mathrm{InsP}_{3}$ in bovine chromaffin cells [80-82]. A parallel increase of InsP $\mathrm{P}_{3}$ and $\left[\mathrm{Ca}^{2+}\right]_{c}$ occurs upon challenging these cells with histamine or angiotensin II [83]. The augmentation of $\left[\mathrm{Ca}^{2+}\right]_{\mathrm{c}}$ elicited by stimulation with histamine is mimicked by direct stimulation with Ins $_{3}$, suggesting that stimulation of histamine receptors is coupled to $\mathrm{InsP}_{3}$ generation and the subsequent stimulation of $\mathrm{InsP}_{3}$ receptors to cause ER $\mathrm{Ca}^{2+}$ release $[84,85]$. Pituitary adenylate cyclase-activating polypeptide (PACAP) has also been shown to enhance both InsP $P_{3}$ production and enhanced $\left[\mathrm{Ca}^{2+}\right]_{c}[86]$. In rat chromaffin cells, stimulation of muscarinic and $\beta_{2}$ adrenergic receptors modulates the amplitude of $\left[\mathrm{Ca}^{2+}\right]_{\mathrm{c}}$ oscillations [87]; such $\mathrm{Ca}^{2+}$ oscillations are dependent on $\mathrm{ER} \mathrm{Ca}^{2+}$ release from heparin-sensitive $\mathrm{Ca}^{2+}$ stores [88].

The functional correlate of histamine-elicited ER $\mathrm{Ca}^{2+}$ release has also been studied. For instance, this $\left[\mathrm{Ca}^{2+}\right]_{c}$ signal activates small-conductance $\mathrm{Ca}^{2+}$-activated $\mathrm{K}^{+}$channels leading to hyperpolarisation of bovine chromaffin cells [33]. In this line is the finding that muscarine produces a $\left[\mathrm{Ca}^{2+}\right]_{\mathrm{c}}$ elevation and an outward $\mathrm{K}^{+}$current, due to activation of $\mathrm{Ca}^{2+}$-activated $\mathrm{K}^{+}$channels in guinea-pig chromaffin cells [89]. These channels are regulating the nicotinic and muscarinic secretory response of cat and bovine chromaffin cells [90-92]. While ER $\mathrm{Ca}^{2+}$ release by histamine causes a mild and transient catecholamine release response [93], a more sustained application causes a longer effect [93-95]. This greater effect could be explained by the fact histamine-elicited $\left[\mathrm{Ca}^{2+}\right]_{c}$ elevations has two components: an initial transient phase due to ER $\mathrm{Ca}^{2+}$ release and a late more sustained phase due to $\mathrm{Ca}^{2+}$ entry $[30,83,96,97]$. The second component has been associated to inhibition of an M-current by sustained histamine application, leading to cell depolarisation, discharge of action potentials and opening of VDCCs in bovine chromaffin cells [98], although stimulation of SOCCs by ER emptying could also contribute to this effect (see Section 2.2). Finally, it is interesting that histamine has been used as a tool to elicit subthreshold $\left[\mathrm{Ca}^{2+}\right]_{c}$ elevations in voltage-clamped bovine chromaffin cells. This $\left[\mathrm{Ca}^{2+}\right]_{\mathrm{c}}$ signal does not elicit exocytosis by itself, but potentiates the subsequent exocytotic response to a depolarising stimulus, likely due to an acceleration of the flow of new vesicles towards exocytotic subplasmalemmal sites [99]. Also, angiotensin II augments $\left[\mathrm{Ca}^{2+}\right]_{\mathrm{c}}$ and secretion in bovine chromaffin cells but to a lesser extent than histamine $[24,100]$. On the other hand, the nicotinic response seems to have a component linked to $\mathrm{ER} \mathrm{Ca}^{2+}$ release [101].
Concerning RyR channels, it has been known for long that bovine chromaffin cells possess a powerful caffeine-sensitive calcium store [102]. The release of $\mathrm{ER} \mathrm{Ca}^{2+}$ by caffeine was later shown to follow a quantal pattern, suggesting that the caffeine-sensitive $\mathrm{Ca}^{2+}$ pool is composed of functionally discrete stores with heterogeneous sensitivities to caffeine $[103,104]$. Additionally, the presence of separate or overlapping $\mathrm{Ca}^{2+}$ pools responsive to either caffeine, $\mathrm{InSP}_{3}$ or cyclic ADP ribose, their differential sensitivity to SERCA inhibitors such as thapsigargin, and the physiological significance or the different $\mathrm{Ca}^{2+}$ release mechanisms, have been subject of debate for many years [85,105-108].

Direct monitoring of changes in the ER $\mathrm{Ca}^{2+}$ concentration $\left(\left[\mathrm{Ca}^{2+}\right]_{\mathrm{ER}}\right)$ in bovine chromaffin cells transfected with ER-targeted aequorin, permitted clarification of some of those issues [22,109]. Thus, $\mathrm{Ca}^{2+}$ entry elicited by depolarisation triggers a transient $\mathrm{Ca}^{2+}$ release from the ER that is highly dependent on $\left[\mathrm{Ca}^{2+}\right]_{E R}$ and sensitised by low caffeine concentrations. On the other hand, caffeine-induced $\mathrm{Ca}^{2+}$ release was quantal in nature due to modulation by $\left[\mathrm{Ca}^{2+}\right]_{\mathrm{ER}}$. Whereas caffeine releases essentially all the $\mathrm{Ca}^{2+}$ from the ER, InsP $\mathrm{P}_{3}$-producing agonists release only $60-80 \%$. However, in digitonin-permeabilised cells both $\mathrm{InsP}_{3}$ and caffeine emptied completely the calcium store while cyclic ADP ribose has no effect. Finally, the wave of $\mathrm{Ca}^{2+}$ elicited by $100 \mathrm{~ms}$ depolarising pulses measured with confocal microscopy, is delayed and reduced in intensity in ryanodine-treated cells. These data suggest that the ER of bovine chromaffin cells behaves as a single thapsigarginsensitive calcium pool that can release $\mathrm{Ca}^{2+}$ both via InsP $\mathrm{P}_{3}$ receptors or CICR. A later report showed that mouse chromaffin cells in the intact gland exhibited a smaller or nonexistent CICR [110]. However, in a recent study performed on cultured mouse chromaffin cells the expression of RyRs and a functional CICR mechanism was shown [111].

In isolated bovine chromaffin cells, caffeine causes a mild secretory response [102], and this effect is also observed in the absence of extracellular $\mathrm{Ca}^{2+}[112,113]$. Activation of CICR during cell depolarisation may have functional consequences for the control of the exocytotic process. In this context, it is interesting that when the $\mathrm{Ca}^{2+}$ store has been depleted by sustained caffeine stimulation, a subsequent depolarisation by high $\mathrm{K}^{+}$elicits a smaller secretion. Consistently, after full ER $\mathrm{Ca}^{2+}$ depletion, the first two or three initial depolarisations contribute to refill the ER with $\mathrm{Ca}^{2+}$ and therefore, the ER behaves as a sink, reducing the amount of $\mathrm{Ca}^{2+}$ available for secretion [113].

In voltage-clamped bovine chromaffin cells, exocytosis is unaffected by previous ER $\mathrm{Ca}^{2+}$ depletion with thapsigargin [114,115]; however, a later study show depressed secretion [115]. In bovine chromaffin cells stimulated with acetylcholine, severe ER $\mathrm{Ca}^{2+}$ depletion with a mixture of caffeine, ryanodine and thapsigargin halves the catecholamine release responses. However, the $\mathrm{K}^{+}$ responses are little affected. This may be due to the fact that acetylcholine elicits discrete and more localised $\left[\mathrm{Ca}^{2+}\right]_{c}$ elevations, whereas $\mathrm{K}^{+}$pulses produce higher $\left[\mathrm{Ca}^{2+}\right]_{c}$ transients that spread quickly throughout the cytosol [116]. This difference may be explained considering that acetylcholine evokes action potentials [117] while $\mathrm{K}^{+}$produces sustained cell depolarisation [118] in bovine chromaffin cells. Thus, it is plausible that the contribution of CICR to the exocytotic response is more visible under conditions of physiological stimulation of chromaffin cells with acetylcholine.

\subsection{Mitochondria}

Mitochondria are the main energy-producing centres of eukaryotic cells $[119,120]$. They are capable of accumulating vast amounts of $\mathrm{Ca}^{2+}$ in their matrix through their $\mathrm{Ca}^{2+}$ uniporter, that uses the driving force of the electrical potential across the mitochondrial membrane [121]. The matrix is more negative than the cytosol, 
with a large transmembrane potential difference (near $-180 \mathrm{mV}$ ) that is generated by the respiratory chain or by ATP hydrolysis. $\mathrm{Ca}^{2+}$ accumulated in mitochondria is then released back into the cytosol by electroneutral antiporters that export $\mathrm{Ca}^{2+}$ from the matrix by swapping one $\mathrm{Ca}^{2+}$ ion for two $\mathrm{Na}^{+}$through the mitochondrial $\mathrm{Na}^{+} / \mathrm{Ca}^{2+}$ exchanger ( $\mathrm{mNCX}$ ). $\mathrm{A} \mathrm{Na}^{+} / \mathrm{H}^{+}$exchange mechanism does also exist, but it is less active than $\mathrm{mNCX}[122,123]$. Additionally, mitochondrial $\mathrm{Ca}^{2+}$-induced $\mathrm{Ca}^{2+}$ release mediated by the calcium uniporter has also been observed [124].

During cell activation, some mitochondria take up $\mathrm{Ca}^{2+}$ from cytosolic HCMDs that are created by the opening of nearby VDCCs $[109,125]$. In rat chromaffin cells, mitochondria act as rapid and reversible $\mathrm{Ca}^{2+}$ buffers during cell stimulation [126,127]; they also contribute to the clearance of large $\mathrm{Ca}^{2+}$ loads in bovine chromaffin cells $[109,128]$. However, early measurements of $\left[\mathrm{Ca}^{2+}\right]$ changes in the mitochondrial matrix $\left(\left[\mathrm{Ca}^{2+}\right]_{\mathrm{M}}\right)$ provides values only in the low micromolar range [126], most probably because underestimation by saturation of the measuring fluorescent $\mathrm{Ca}^{2+}$ probe. By using mitochondrially targeted aequorins with different $\mathrm{Ca}^{2+}$ affinities, which have a much wider dynamic range [52,129], it was later on shown that bovine chromaffin cell mitochondria exhibit surprisingly rapid millimolar $\mathrm{Ca}^{2+}$ transients upon cell stimulation with acetylcholine, caffeine or $\mathrm{K}^{+}$[130].

This avid $\mathrm{Ca}^{2+}$ uptake by mitochondria surely has functional consequences. For instance, dissipation of the proton gradient by protonophores decreases the $\mathrm{Ca}^{2+}$ buffering capacity of mitochondria [130,131] and drastically augments the exocytotic response in voltage-clamped bovine chromaffin cells stimulated with depolarising pulses [132]. In perifused populations of bovine chromaffin cells stimulated with acetylcholine, caffeine or $\mathrm{K}^{+}$, mitochondrial protonophores enhance 3-5 fold the release of catecholamines [116,130,133]. Blockade of the mitochondrial calcium uniporter also enhances the $\mathrm{K}^{+}$-evoked secretion in single bovine chromaffin cells [131]. $\mathrm{K}^{+}$-elicited secretion is particularly augmented by protonophores when $\mathrm{Ca}^{2+}$ entry via L-type VDCCs is enhanced by FPL64176 [134]. In mouse chromaffin cells however, protonophores halved the $\mathrm{K}^{+}$-evoked $\left[\mathrm{Ca}^{2+}\right]_{\mathrm{c}}$ and catecholamine release responses [135]; this could be explained by differences in the expression of VDCC subtypes in bovine versus mouse chromaffin cells, and/or different rates of inactivation of VDCC subtypes during blockade of mitochondrial $\mathrm{Ca}^{2+}$ uptake by protonophores [136].

\section{Calcium efflux}

The main transporters used by cells to extrude $\mathrm{Ca}^{2+}$ from the intracellular to the extracellular compartment are the plasmalemmal $\mathrm{Ca}^{2+}$ pump or $\mathrm{Ca}^{2+}$-ATPase and the $\mathrm{Na}^{+} / \mathrm{Ca}^{2+}$ exchanger (NCX) (Fig. 1). Both transporters contribute to maintain the long-term $\mathrm{Ca}^{2+}$ homeostasis through a well balanced $\mathrm{Ca}^{2+}$ influx and $\mathrm{Ca}^{2+}$ efflux activities. The functional expression of these two transporters was first demonstrated using plasma membrane vesicles from bovine adrenal medulla [137]. The plasmalemmal $\mathrm{Ca}^{2+}$ ATPase has a high $\mathrm{Ca}^{2+}$ affinity ( $K_{\mathrm{D}}$ in the $10^{-7} \mathrm{M}$ range) and operates as an electrogenic $\mathrm{Ca}^{2+} / \mathrm{H}^{+}$exchanger with a $1: 1$ stoichiometry [138].

The NCX uses the energy provided by the $\mathrm{Na}^{+}$gradient to achieve an electrogenic exchange of $3 \mathrm{Na}^{+}$ions for $1 \mathrm{Ca}^{2+}$ ion. Under physiological conditions $\mathrm{Na}^{+}$is transported into the cell and $\mathrm{Ca}^{2+}$ is extruded from the cytosol [139]. However, when the electrochemical gradient for $\mathrm{Na}^{+}$is reversed, such as during membrane depolarisation or the opening of gated $\mathrm{Na}^{+}$channels, the exchanger moves $\mathrm{Na}^{+}$out of the cell and $\mathrm{Ca}^{2+}$ into the cell [140]. The $\mathrm{Ca}^{2+}$ exit mode is referred to as the forward mode, and the $\mathrm{Ca}^{2+}$ entry mode as the reverse mode of the NCX [141]. Bovine chromaffin cells express the major isoform of the NCX, namely NCX1 [142], which can mediate $\mathrm{Na}^{+}$-dependent $\mathrm{Ca}^{2+}$ influx [143] or $\mathrm{Ca}^{2+}$ export [144], depending on the circumstances.

The cardiotonic steroid ouabain, the classical inhibitor of the plasmalemmal $\mathrm{Na}^{+} / \mathrm{K}^{+}$-ATPase (NKA) or $\mathrm{Na}^{+}$pump [145] has been widely used to infer the role of the NCX in various cell types. Although ouabain upsets primarily the $\mathrm{Na}^{+}$and $\mathrm{K}^{+}$gradients across the plasma membrane, the collapse of the $\mathrm{Na}^{+}$gradient can secondarily drive $\mathrm{Ca}^{2+}$ entry though NCX. This is the mechanism underlying the heart inotropic effect of cardiac glycosides. On the other hand, repeated action potential firing leading to $\mathrm{Na}^{+}$accumulation, can also force NCX to work in reverse mode, thereby increasing $\left[\mathrm{Ca}^{2+}\right]_{c}$ and favouring the replenishment with $\mathrm{Ca}^{2+}$ of the sarcoplasmic reticulum. During subsequent action potentials, augmented CICR, which is potentiated by the increased $\left[\mathrm{Ca}^{2+}\right]_{E R}$, leads to enhanced cardiac contraction [146].

Since long we know that ouabain enhances both the spontaneous [147-149] and the $\mathrm{K}^{+}$-evoked catecholamine release from cat chromaffin cells [150] and bovine chromaffin cells [151,152]. These effects were initially interpreted as a secondary activation of the NCX by ouabain $[143,153,154]$, through a mechanism similar to that occurring in the heart. However, an alternative explanation can be inferred from the recent observation that NKA co-localises with subplasmalemmal regions of the ER $[155,156]$. Recent data on bovine chromaffin cells show that ouabain causes the release of $\mathrm{Ca}^{2+}$ from the ER and augments the catecholamine secretory responses to sequential $\mathrm{K}^{+}$pulses. ER $\mathrm{Ca}^{2+}$ depletion prevents such potentiation and causes a gradual decrease of the responses to $\mathrm{K}^{+}$. Furthermore, ouabain enhances the number of docked vesicles at subplasmalemmal regions, as revealed with TIRF microscopy [152]. All these data support earlier suggestions that the ER $\mathrm{Ca}^{2+}$ store contributes to maintain healthy secretory responses elicited by depolarising pulses applied to bovine chromaffin cells $[115,116]$. The fact that endogenous ouabain has been identified in human plasma $[157,158]$ and that bovine adrenal cortex is particularly rich in endogenous ouabain [159], suggests a physiological role of this mediator in the control of $\mathrm{Ca}^{2+}$-dependent vesicle flow from a reserve pool towards ready-release and immediate-release vesicle pools at subplasmalemmal sites [7].

Bovine chromaffin cells express the major isoform of the NCX, NCX1 [160]. In bovine chromaffin cells NCX1 can favour $\mathrm{Na}^{+}$-dependent $\mathrm{Ca}^{2+}$ influx [143] or $\mathrm{Ca}^{2+}$ export [144] and has been proposed to participate in the regulation of $\left[\mathrm{Ca}^{2+}\right]_{c}$ and exocytosis in cat $[150,161,162]$ and bovine chromaffin cells $[142,143,153,163-165]$. In addition, chromaffin cells co-express NCX and the retinal rod-type $\mathrm{K}^{+}$-dependent $\mathrm{Na}^{+} / \mathrm{Ca}^{2+}$ exchanger [166]. Attempts to clarify the participation of the NCX in physiological and pathological processes have been hampered by the lack of potent and selective blockers. The antagonist KB-R7943 preferentially inhibits, at low micromolar concentrations, the reverse mode of the NCX [167]. Unfortunately, this compound also blocks other transporters, such as the mitochondrial uniporter [168], and the nicotinic receptors of bovine chromaffin cells [169]. Novel and more selective inhibitors such as SEA0400, SN-6 and YM-244769 [170] should help to further clarify the role of the NCX in $\mathrm{Ca}^{2+}$ signalling and exocytosis in chromaffin cells. In fact, SEA0400 inhibits $\mathrm{Na}^{+}$-dependent $\mathrm{Ca}^{2+}$ uptake and catecholamine release in bovine chromaffin cells, with $\mathrm{IC}_{50}$ of 40 and $100 \mathrm{nM}$, respectively, compared with $\mathrm{IC}_{50}$ of 1.8 and $3.7 \mu \mathrm{M}$ for KB-R7943, that was 40 -fold less potent [171].

\section{A functional tetrad shapes calcium gradients and calcium microdomains}

In the intact organism, the fight or flight stress response is triggered by acetylcholine, the physiological neurotransmitter at the 


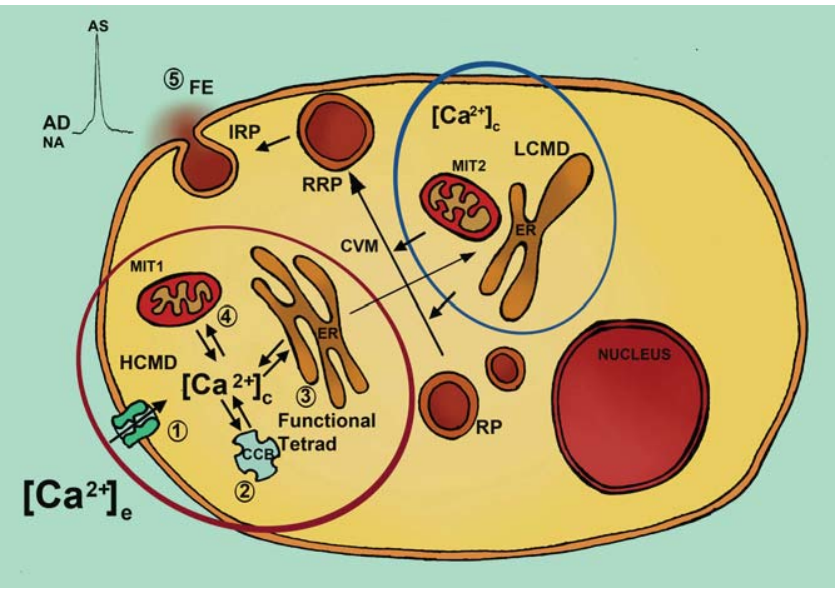

Fig. 2. Functional tetrads to shape the high- $\mathrm{Ca}^{2+}$ microdomains (HCMDs) an low$\mathrm{Ca}^{2+}$ microdomains (LCMDs) that determine, respectively, the fast exocytosis (FE) release of adrenaline (AD) and noradrenaline (NA), from an immediately releasable vesicle pool (IRP), and chromaffin vesicles movement (CVM) from a reserve pool (RP). Tetrads are formed by voltage-dependent $\mathrm{Ca}^{2+}$ channels (1, VDCCs), cytosolic $\mathrm{Ca}^{2+}$ buffers (2, CCB), the endoplasmic reticulum (3, ER) and the mitochondrial pool 1 (MIT1) located nearby the plasmalemma (4). This tetrad (red line) is responsible for generating and shaping the HCMD transients $(10-100 \mu \mathrm{M})$, nearby subplasmalemmal exocytotic sites, to trigger fast catecholamine release from the IRP, that can be monitored at the single-vesicle level as amperometric spikes (AS) with a carbon fibre microelectrode (5). The LCMD $(<1 \mu \mathrm{M})$ is located at cytosolic sites away from the plasmalemma, and facilitate the $\mathrm{Ca}^{2+}$-dependent CVM. Crosstalk between HCMD and LCMD is needed to secure the supply of new vesicles to the secretory machinery under different stimulation rates of chromaffin cells (see text for further details).

synapse of the splanchnic nerve and chromaffin cells [1]. Direct membrane depolarisation or action potentials fired by the interaction of acetylcholine with nicotinic receptors on the surface of chromaffin cells [117] is likely the primary stimulus that induces the $\left[\mathrm{Ca}^{2+}\right]_{\mathrm{c}}$ transient, thus triggering the discharge of adrenaline and noradrenaline into the circulation [38]. $\mathrm{Ca}^{2+}$ entry through the various subtypes of VDCCs is the primary determinant for the extent and shape of the initial $\left[\mathrm{Ca}^{2+}\right]_{c}$ transient. However, cytosolic calcium buffers, $\mathrm{Ca}^{2+}$ sequestration or release from the cytoplasmic organelles, and plasmalemmal $\mathrm{Ca}^{2+}$ extrussion have a prominent role in the fine tuning of the $\mathrm{Ca}^{2+}$ signal. On the other hand, correct $\mathrm{Ca}^{2+}$ signalling is critical to warrant the adaptation of the entire organism to a stress response which determines its survival. We will emphasise here our present integrative view of the biophysics of $\mathrm{Ca}^{2+}$ redistribution, which is the ultimate regulator of the exocytotic response (Fig. 2).

Essential to the understanding of $\mathrm{Ca}^{2+}$ function in chromaffin cells is the concept that organelles and cytosolic calcium buffers shape $\left[\mathrm{Ca}^{2+}\right]_{c}$ transients at different cell locations, the so-called HCMDs, that do not necessarily crosstalk. Several kinds of these HCMDs have been described in different cell systems and given evocative names, such as sparks, puffs, sparklets and syntillas $[172,173]$. Syntillas are brief focal $\left[\mathrm{Ca}^{2+}\right]_{c}$ transients elicited by localised $\mathrm{ER} \mathrm{Ca}^{2+}$ release via RyR channels, first reported in neurohypophysial terminals at magnocellular neurons [174]. These focal $\mathrm{Ca}^{2+}$ transients were later on found in mouse chromaffin cells [175] and, paradoxically, they seem to block spontaneous exocytosis in these cells [176]. Because CICR is present in bovine chromaffin cells, it could be of interest to investigate whether the $\mathrm{Ca}^{2+}$ wave that extends from subplasmalemmal sites to the inner cytosol following a $100 \mathrm{~ms}$ depolarising pulse and CICR activation [22], is composed of elementary syntillas. We have recently found that nanomolar concentrations of the wine grape polyphenol resveratrol causes ER $\mathrm{Ca}^{2+}$ release in bovine chromaffin cells and, at the same time, it blocks the quantal catecholamine release response [177]. It would be interesting to clarify whether these effects of resveratrol are linked to the production of $\mathrm{Ca}^{2+}$ syntillas. It seems however that the presence and functional role for $\mathrm{Ca}^{2+}$ syntillas are seriously questioned and controversial. In fact, caffeine or ryanodine do not augment $\left[\mathrm{Ca}^{2+}\right]_{\mathrm{c}}$ and neuropeptide release at neurohypophysial terminals $[178,179]$.

The rate of $\mathrm{Ca}^{2+}$ fluxes between different chromaffin cell compartments have been estimated using more or less direct approaches, and under temperature conditions (i.e. room temperature) that might affect the activity of some $\mathrm{Ca}^{2+}$ transporters. Even with these limitations, putting together the estimates of the different fluxes allows for several interesting predictions [109]. For instance, for a $15-\mu \mathrm{m}$ diameter bovine chromaffin cell, a rate of $\mathrm{Ca}^{2+}$ entry of $700 \mu \mathrm{mol} \mathrm{L}$ cells ${ }^{-1} \mathrm{~s}^{-1}$ can be computed from the measured $\mathrm{Ca}^{2+}$ inward current [180]. A similar value $\left(400 \mu \mathrm{mol} \mathrm{L} \mathrm{cells}{ }^{-1} \mathrm{~s}^{-1}\right)$ was estimated by measuring ${ }^{45} \mathrm{Ca}^{2+}$ uptake into $\mathrm{K}^{+}$depolarised bovine chromaffin cells [181]. $\mathrm{Ca}^{2+}$ entry would be focused at the channels location and then diffuse through the surrounding cytosol.

Regarding progression of the $\mathrm{Ca}^{2+}$ wave generated by $\mathrm{Ca}^{2+}$ entry through plasma membrane $\mathrm{Ca}^{2+}$ channels, binding to cytosolic calcium buffers is a most important determinant. The cytosol of bovine chromaffin cells has a $\mathrm{Ca}^{2+}$ binding capacity of $\sim 4 \mathrm{mmol} / \mathrm{L}$ cells. The cytosolic calcium buffers are scarcely mobile and have a low $\mathrm{Ca}^{2+}$ affinity $\left(K_{\mathrm{D}} \sim 100 \mu \mathrm{M}\right)$ with an activity coefficient of $\sim 1 / 40$ $[128,180]$. The two-dimensional diffusion coefficient is $\sim 40 \mu \mathrm{m}^{2} / \mathrm{s}$ and shows inhomogeneities at the nuclear envelope and at the plasma membrane [53]. Brief openings of VDCCs generate HCMDs near the channel mouth that can be detected in $\mathrm{Ca}^{2+}$ imaging measurements [182]. These HCMDs can reach concentrations as high as $10-100 \mu \mathrm{M}[7,182]$ Because of rapid diffusion of $\mathrm{Ca}^{2+}$ towards the surrounding cytosol, the HCMDs are highly restricted in time and space $[7,183]$. The presence of mobile calcium buffers accelerates diffusion and opposes the development of HCMDs [180,184-186]; for example, at concentrations of $50 \mu \mathrm{M}$, fura- 2 increases the apparent rate of $\mathrm{Ca}^{2+}$ diffusion four times [180].

$\mathrm{Ca}^{2+}$ entering the cell redistributes among the different cell compartments. The increase of $\left[\mathrm{Ca}^{2+}\right]_{\mathrm{c}}$ activates the SERCA and the ER avidly takes up $\mathrm{Ca}^{2+}$ from the cytosol. For example, during stimulation of bovine chromaffin cells $[22,109,128]$ and rat chromaffin cells [187], the maximal $\mathrm{Ca}^{2+}$ uptake by the ER ranges between 40 and $80 \mu \mathrm{mol} \mathrm{Lcells}{ }^{-1} \mathrm{~s}^{-1}$. At rest, the rate of $\mathrm{Ca}^{2+}$ exchange between ER and cytosol at steady state is $2-3 \mu \mathrm{mol} \mathrm{L}$ cells ${ }^{-1} \mathrm{~s}^{-1}$. The net $\mathrm{Ca}^{2+}$ influx upon maximal stimulation with caffeine or Ins $\mathrm{P}_{3}$-producing agonists is 10-20 times faster [22].

Concerning mitochondria, it is notorious that the $\mathrm{Ca}^{2+}$ activity coefficient (free $\mathrm{Ca}^{2+} /$ bound calcium) in the matrix is very low, in the $1 / 1000$ range $[109,126]$. Mitochondria are very effective in the clearing of $\left[\mathrm{Ca}^{2+}\right]_{c}$ transients, although drastic differences have been reported between bovine and rat chromaffin cells. For instance, in experiments with photorelease of caged $\mathrm{Ca}^{2+}$ in bovine chromaffin cells, rates of $\left[\mathrm{Ca}^{2+}\right]_{M}$ increase as high as $4800 \mu \mathrm{mol} \mathrm{L}$ cells ${ }^{-1} \mathrm{~s}^{-1}$, at saturating $\left[\mathrm{Ca}^{2+}\right]_{\mathrm{c}}(200 \mu \mathrm{M})$, were found [128]. In contrast, in rat chromaffin cells, mitochondrial uptake rates are $150-300$ fold slower but at $\left[\mathrm{Ca}^{2+}\right]_{c}$ of only $0.2-2 \mu \mathrm{M}$, were found [187]. These differences are consistent with dependence of the rate of uptake through the uniporter on the second power of $\left[\mathrm{Ca}^{2+}\right]_{c}[123,124,130,188]$. Using mitochondria-targeted aequorin to specifically monitor $\left[\mathrm{Ca}^{2+}\right]_{\mathrm{M}}$, we found that mitochondria took up about $1100 \mu \mathrm{mol}$ Lcells $^{-1} \mathrm{~s}^{-1}$ upon maximal stimulation of $\mathrm{Ca}^{2+}$ entry into bovine chromaffin cells depolarised with $\mathrm{K}^{+}[109,124,130]$; this value is comparable with the rate of $\mathrm{Ca}^{2+}$ entry through VDCCs. The maximal rate of $\mathrm{Ca}^{2+}$ release from mitochondria trough the $\mathrm{mNCX}$ at $37^{\circ} \mathrm{C}$ in bovine chromaffin cells is about $800 \mu \mathrm{mol} \mathrm{L}$ cells ${ }^{-1} \mathrm{~s}^{-1}$. Regarding the kinetics of this mitochondrial $\mathrm{Ca}^{2+}$ efflux, the dependence on $\left[\mathrm{Ca}^{2+}\right]_{\mathrm{M}}$ is exponential and $K_{50}$ approaches $200 \mu \mathrm{M}$ [109]. Transport through the uniporter is usually unidirectional (entry); however, when mitochondria are 
completely depolarised, the uniporter may allow $\mathrm{Ca}^{2+}$ exit from the matrix in a sort of mitochondrial CICR mechanism [124].

$\mathrm{Ca}^{2+}$ extrusion from the cell to the extracellular medium is due to joint operation of both $\mathrm{Ca}^{2+}$-ATPase and NCX. The joint action of both transport systems has been estimated to decrease $\left[\mathrm{Ca}^{2+}\right]_{\mathrm{c}}$ to a maximal rate of $20 \mu \mathrm{mol} \mathrm{L}$ cells $\mathrm{s}^{-1} \mathrm{~s}^{-1}$, in rat chromaffin cells at $27^{\circ} \mathrm{C}$ $[127,187]$. At $37^{\circ} \mathrm{C}$ the rate can be close to $100 \mu \mathrm{mol} \mathrm{L} \mathrm{cells}^{-1} \mathrm{~s}^{-1}$ [109].

At each and every moment the $\left[\mathrm{Ca}^{2+}\right]_{\mathrm{c}}$ is defined by the rate of $\mathrm{Ca}^{2+}$ redistribution into chromaffin cell compartments which in turn depends on fluxes between the extracellular medium, the cytosol, cytosolic calcium buffers and organelles. At rest, a steady state with $\mathrm{Ca}^{2+}$ exchange rates below $10 \mu \mathrm{mol} \mathrm{Leells}{ }^{-1} \mathrm{~s}^{-1}$ and $\left[\mathrm{Ca}^{2+}\right]_{\mathrm{c}}$ near $0.1 \mu \mathrm{M}$ is established; $\left[\mathrm{Ca}^{2+}\right]_{\mathrm{M}}$ is similar to $\left[\mathrm{Ca}^{2+}\right]_{\mathrm{C}}$ while $\left[\mathrm{Ca}^{2+}\right]_{E R}$ is much higher, reaching $500-1000 \mu \mathrm{M}$. Consequently, there are enormous electrochemical gradients favouring $\mathrm{Ca}^{2+}$ diffusion to the cytosol from both, the ER and the extracellular medium where the $\mathrm{Ca}^{2+}$ concentration is above $1 \mathrm{mM}$.

At low-frequency stimulation with action potentials, the rate of $\mathrm{Ca}^{2+}$ diffusion through the cytosol and binding by the endogenous $\mathrm{Ca}^{2+}$ buffers are the main determinants of the $\left[\mathrm{Ca}^{2+}\right]_{\mathrm{c}}$ signal $[7,183]$. Under these conditions, global $\left[\mathrm{Ca}^{2+}\right]_{c}$ goes up to about $1 \mu \mathrm{M}$ and $\mathrm{Ca}^{2+}$ clearance is primarily achieved through the high-affinity $\mathrm{Ca}^{2+}$-ATPase and SERCA. Upon strong stimulation (high-frequency action potentials or prolonged depolarisation), global $\left[\mathrm{Ca}^{2+}\right]_{\mathrm{c}}$ may approach $10 \mu \mathrm{M}$, a concentration high enough to activate $\mathrm{Ca}^{2+}$ uptake through the mitochondrial uniporter. Under these conditions, most of the $\mathrm{Ca}^{2+}$ that enters chromaffin cells is taken up by mitochondria $[109,127,130,187]$. For example, mitochondriatargeted aequorin revealed that $90 \%$ of the $\mathrm{Ca}^{2+}$ that enters a bovine chromaffin cell stimulated with a $10-\mathrm{s} \mathrm{K}^{+}$pulse is taken up by mitochondria. Later, when the stimulation ceases, the $\mathrm{Ca}^{2+}$ accumulated in mitochondria is released back to the cytosol during a period of seconds or even minutes [109]. The $\mathrm{Ca}^{2+}$ accumulated in mitochondria stimulates respiration until $\mathrm{Ca}^{2+}$ extrusion from the mitochondrial matrix is complete [109]. It can be speculated that the extra energy provided in this way may be used for clearing the $\mathrm{Ca}^{2+}$ load and restoring $\mathrm{Ca}^{2+}$ homeostasis after the activity period.

In bovine chromaffin cells, the opening of VDCCs generates HCMDs of about $0.3 \mu \mathrm{m}$ diameter and $10 \mu \mathrm{M}\left[\mathrm{Ca}^{2+}\right]_{\mathrm{c}}$ [99,182,189-191]. Building of HCMDs may be favoured by colocalisation of VDCC clusters and chromaffin vesicles [31,192,193]. Evanescent microscopy has shown fast $\left(t_{1 / 2} \sim 100 \mathrm{~ms}\right)$ and localised $(\sim 350 \mathrm{~nm})$ HCMDs beneath the plasma membrane of stimulated chromaffin cells [194]. These HCMDs selectively trigger the release of vesicles docked within $300 \mathrm{~nm}$, indicating that some vesicles are docked but not primed. It is interesting that HCMDs reduce the distance between docked vesicles and $\mathrm{Ca}^{2+}$ entry sites, suggesting a role for stimulation-dependent facilitation of exocytosis in chromaffin cells [193,194].

Mitochondria located nearby VDCCs at subplasmalemmal sites can sense HCMDs during physiological stimulation $[109,127,130,187,195]$. Through measurements of aequorin consumption upon repeated stimulation of bovine chromaffin cells, the cumulative history of $\mathrm{Ca}^{2+}$ uptake may be traced. Using this approach, two pools of mitochondria with different subcellular distribution were evidenced. Pool M1, located nearby exocytotic sites, accumulates $\left[\mathrm{Ca}^{2+}\right]_{\mathrm{c}}$ at a rate of $2000 \mu \mathrm{mol} \mathrm{Lcells} \mathrm{s}^{-1} \mathrm{~s}^{-1}$, while pool M2 located at inner cytosolic areas takes up $\mathrm{Ca}^{2+}$ at a much lower rate, $12 \mu \mathrm{mol} \mathrm{L} \mathrm{cells}{ }^{-1} \mathrm{~s}^{-1}[109,130]$. These rates are reached at concentrations of 20 and $2 \mu \mathrm{M}\left[\mathrm{Ca}^{2+}\right]_{\mathrm{c}}$ respectively, which are coincident with the concentrations reached at subplasmalemmal sites and the cell core during cell stimulation. The M1 pool would tune the mitochondrial function to match the local energy needs for exocytosis and $\mathrm{Ca}^{2+}$ redistribution whereas the $\mathrm{M} 2$ pool, located at the bulk cytosol, could serve to redistribute $\mathrm{Ca}^{2+}$ and canalize it towards inner cytosolic regions to serve other cell functions, i.e. transport of new secretory vesicles to plasmalemmal exocytotic sites.

$\mathrm{ER} \mathrm{Ca}^{2+}$ fluxes could also contribute to the regulation of HCMDs formed during cell stimulation. For instance, under $\mathrm{K}^{+}$depolarisation of bovine chromaffin cells transfected with ER-targeted aequorin, reductions of $60-100 \mu \mathrm{M}\left[\mathrm{Ca}^{2+}\right]_{\mathrm{ER}}$ are observed (about $10-15 \%$ of the total ER Ca ${ }^{2+}$ content) [22], suggesting $\mathrm{Ca}^{2+}$-induced $\mathrm{Ca}^{2+}$ release. Although the decrease of $\left[\mathrm{Ca}^{2+}\right]_{\mathrm{ER}}$ may seem quite small, it could correspond to large release at certain subcellular ER locations compensated by strong uptake in others. CICR sites seem to co-localise with plasmalemmal VDCCs and the M1 mitochondrial pool. Thus, complex functional tetrads including VDCCs, cytosolic calcium buffers, the mitochondrial uniporter and the RyR are essential for the efficacious regulation of adequate local $\left[\mathrm{Ca}^{2+}\right]_{c}$ transients to control the rate and extent of exocytotic catecholamine release (Fig. 2).

\section{Relationship between calcium and the exo-endocytotic responses}

A few studies have addressed the question of the quantitative relationship between $\mathrm{Ca}^{2+}$ and the exo-endocytotic responses triggered by chromaffin cell stimulation. One approach consists in the dialysis of bovine chromaffin cells with solutions containing known $\left[\mathrm{Ca}^{2+}\right]$ to elicit secretion, measured as an increase of membrane capacitance $(\Delta \mathrm{Cm})$ [32]. Also caffeine is used to augment $\left[\mathrm{Ca}^{2+}\right]_{\mathrm{c}}$ and measure $\Delta \mathrm{Cm}$ [196]. Both approaches lead to a $\left[\mathrm{Ca}^{2+}\right]_{c}$-exocytosis relationship that scaled to a power function with an exponent of 3 . Still other studies use voltage steps (square depolarising pulses) to boost $\mathrm{Ca}^{2+}$ influx $\left(Q_{\mathrm{Ca}}\right)$ and exocytosis; they found a $Q_{c a} / \triangle \mathrm{Cm}$ relationship that fitted a power function with an exponent of $1.5[197,198]$. There are additional studies in bovine chromaffin cells stimulated with single or trains of depolarising pulses [199] or action potential waveform trains as well as $100 \mathrm{~ms}$ depolarising pulses [132]. The longer depolarising pulses produced $Q_{C a} / \Delta C m$ relationships that fitted to power functions of $1.2-2$. In line with these conclusions is the observation in rat chromaffin cells stimulated with single depolarising pulses of increasing length (10-150 ms), showing a linear $Q_{c a} / \Delta C m$ relationship [200]. Flash photolysis of caged $\mathrm{Ca}^{2+}$ has also been used to study the kinetic components of a fast exocytotic burst [201]. Depolarising pulses are known to be much less efficient than $\mathrm{Ca}^{2+}$ photorelease in triggering exocytosis [202,203].

Other studies have used action potential waveforms to correlate the stimulation frequency in bovine chromaffin cells with amperometric spike secretion in rat chromaffin cells [192] or with capacitance increase in bovine chromaffin cells [204]. In addition, depolarising pulses have been used in transgenic mice to study the role of exocytotic proteins on the kinetics of $\Delta \mathrm{Cm}$ [203]. On the other hand, a study comparing depolarising pulses of increasing length with acetylcholine-type action potentials in voltage-clamped bovine chromaffin cells, found less $\mathrm{Ca}^{2+}$ entry and slower activation of $\left[\mathrm{Ca}^{2+}\right]_{c}$ transients with faster delayed decay. With action potentials a linear relationship is found between $Q_{\mathrm{Ca}}$ and stimulus duration, capacitance increase and stimulus duration and $Q_{C a}$ and capacitance increase. These relationships are nonlinear with depolarising pulses. Furthermore, capacitance increase responses elicited by action potential trains are followed by little slow endocytosis, while those induced by depolarising pulses are followed by a pronounced endocytosis, particularly at the longer pulses [205].

Controversy exists over the manner in which membrane retrieval during endocytosis is affected by $\mathrm{Ca}^{2+}$. For instance, compensatory and excess endocytosis represent two independent $\mathrm{Ca}^{2+}$-regulated mechanisms of rapid internalisation in bovine 
chromaffin cells $[204,206]$. The existence of these two $\mathrm{Ca}^{2+}$ sensors is consistent with the fact that $\mathrm{Ca}^{2+}$ and $\mathrm{Ba}^{2+}$ support excessive membrane retrieval in bovine chromaffin cells [207]. In contrast, a previous study in the same cells showed that rapid endocytosis was supported by $\mathrm{Ca}^{2+}$ but not by $\mathrm{Sr}^{2+}$ or $\mathrm{Ba}^{2+}[208]$. A recent study shows a linear correlation between endocytosis and $Q_{C a}$ in voltage-clamped bovine chromaffin cells [209].

It is interesting that $\mathrm{Ca}^{2+}$-dependent endocytosis triggered by single long depolarising pulses in voltage-clamped bovine chromaffin cells seems to be coupled to L-type VDCCs, whereas N- or PQ-type of calcium channels seem to play little role [210,211]. Lack of co-localisation between VDCC subtypes and clathrin or dynamin suggests a functional, rather than physical coupling between L-type calcium channels and the endocytotic machinery. In bovine chromaffin cells, L-type calcium channels undergo a $\mathrm{Ca}^{2+}$-dependent inactivation slower than $\mathrm{N}$ - or PQ-type of calcium channels [136,212]. It is therefore plausible that a slower but more sustained $\mathrm{Ca}^{2+}$ entry through slowly inactivating L-type calcium channels, rather than through higher but fast-inactivating $\mathrm{N}$ and PQ-type of calcium channels, is a requirement to trigger endocytosis efficiently, at least in bovine chromaffin cells [211]. This $\mathrm{Ca}^{2+}$-dependent endocytotic response is enhanced by sphingosine dialysis, that seems to play a permissive role for endocytosis by acting on an endocytotic pathway different to those of dynamin- and calmodulin-signalling pathways [209].

\section{Conclusions and perspectives}

A number of studies have clarified the role of several families of ion channels and transporters in shaping the $\left[\mathrm{Ca}^{2+}\right]_{\mathrm{c}}$ signals and the exo-endocytotic responses occurring during chromaffin cell stimulation. From the 1970s onwards most of the studies were performed in ready available bovine chromaffin cells. During the last two decades, however, chromaffin cells from rats have also been thoroughly used. It is surprising, however, that only few studies on $\mathrm{Ca}^{2+}$ handling in mouse chromaffin cells have been performed. Transgenic mice lacking or over-expressing a given protein have extensively been used to clarify molecular mechanisms of the secretory machinery. It would be very interesting to use chromaffin cells as models to identify alterations of $\mathrm{Ca}^{2+}$ homeostatic mechanisms and the release of catecholamines in mouse models of disease. For instance, in transgenic mouse models of Alzheimer's disease, amyotrophic lateral sclerosis, Parkinson's disease and other neurodegenerative diseases, the expectation is that high and low $\mathrm{Ca}^{2+}$ microdomains may differently affect pre- and exocytotic steps, which could be a peripheral marker of a brain synaptic dysfunction. There is increasing concern on the involvement of $\mathrm{Ca}^{2+}$ dyshomeostasis in these diseases [213-216].

Whether the large $\mathrm{Ca}^{2+}$ concentrations in chromaffin vesicles play a function other than the mere packing of catecholamine such as for instance, contributing to regulation of the last steps of exocytosis, requires further clarification. We also know little on the role of $\mathrm{Ca}^{2+}$ fluxes in the chromaffin cell nucleus, although they are likely involved in the control of gene expression. It would be nice to know, for example, whether such nuclear $\mathrm{Ca}^{2+}$ signalling is involved in the expression of the enzymes of catecholamine synthesis and degradation.

Efforts should also be done to extrapolate the numerous data obtained in cultures of chromaffin cells to more physiological preparations such as adrenal slices or even the intact adrenal, using electrical stimulation of the sympathetic cholinergic nerve terminals that innervate chromaffin cells to regulate secretion. Attempts to establish organotypic cultures of adrenal slices should also be pursued, as this could facilitate chronic treatments to study novel aspects of catecholamine synthesis, storage and release and on the role of $\mathrm{Ca}^{2+}$ signalling under these more physiological conditions of preservation of tissue structure.

\section{Acknowledgements}

The work of the author's laboratories has been supported by the following institutions. To AGG: (1) SAF2010-21795, Ministerio de Ciencia e Innovación (MCINN); (2) RETICS RD06/0009, Instituto de Salud Carlos III (MICINN); (3) S-SAL-0275-2006, Comunidad Autónoma de Madrid; (4) NDG07/9 y NDG09/8, Agencia Laín Entralgo, Comunidad Autónoma de Madrid, Spain. (5) Fundación Teófilo Hernando. To JGS: grants from the EU-ERA-Net programme, the Spanish Ministerio de Ciencia e Innovación (MICINN; SAF200803175-E and BFU2010-17379), the Instituto de Salud Carlos III (RD06/0010/0000) and the Junta de Castilla y León (gr175).

\section{References}

[1] W. Feldberg, B. Mintz, Die wirkung von azetylcholin auf die nebennieren, Arch. Exp. Pathol. Pharmakol. 168 (1932) 287-291.

[2] W.W. Douglas, R.P. Rubin, The role of calcium in the secretory response of the adrenal medulla to acetylcholine, J. Physiol. 159 (1961) 40-57.

[3] W.W. Douglas, A.M. Poisner, On the mode of action of acetylcholine in evoking adrenal medullary secretion: increased uptake of calcium during the secretory response, J. Physiol. 162 (1962) 385-392.

[4] W.W. Douglas, Stimulus-secretion coupling: the concept and clues from chromaffin and other cells, Br. J. Pharmacol. 34 (1968) 451-474.

[5] O. Shimomura, The discovery of aequorin and green fluorescent protein, J. Microsc. 217 (2005) 1-15.

[6] R. Rizzuto, M. Brini, T. Pozzan, Intracellular targeting of the photoprotein aequorin: a new approach for measuring, in living cells, $\mathrm{Ca}^{2+}$ concentrations in defined cellular compartments, Cytotechnology 11 (Suppl. 1) (1993) S44-S46.

[7] E. Neher, Vesicle pools and $\mathrm{Ca}^{2+}$ microdomains: new tools for understanding their roles in neurotransmitter release, Neuron 20 (1998) 389-399.

[8] R.D. Burgoyne, A. Morgan, Secretory granule exocytosis, Physiol. Rev. 83 (2003) 581-632.

[9] A.G. Garcia, A.M. Garcia-De-Diego, L. Gandia, R. Borges, J. Garcia-Sancho, Calcium signaling and exocytosis in adrenal chromaffin cells, Physiol. Rev. 86 (2006) 1093-1131.

[10] J. Garcia-Sancho, A. Verkhratsky, Cytoplasmic organelles determine complexity and specificity of calcium signalling in adrenal chromaffin cells, Acta Physiol. (Oxf.) 192 (2008) 263-271.

[11] A.M. de Diego, L. Gandia, A.G. Garcia, A physiological view of the central and peripheral mechanisms that regulate the release of catecholamines at the adrenal medulla, Acta Physiol. (Oxf.) 192 (2008) 287-301.

[12] B.M. Olivera, G.P. Miljanich, J. Ramachandran, M.E. Adams, Calcium channel diversity and neurotransmitter release: the omega-conotoxins and omegaagatoxins, Annu. Rev. Biochem. 63 (1994) 823-867.

[13] E. Garcia-Palomero, I. Cuchillo-Ibanez, A.G. Garcia, J. Renart, A. Albillos, C. Montiel, Greater diversity than previously thought of chromaffin cell $\mathrm{Ca}^{2+}$ channels, derived from mRNA identification studies, FEBS Lett. 481 (2000) 235-239.

[14] M.J. Berridge, Inositol trisphosphate and calcium signaling, Ann. N.Y. Acad. Sci. 766 (1995) 31-43

[15] J.W. Putney, The physiological function of store-operated calcium entry, Neurochem. Res. 36 (2011) 1157-1165.

[16] J.W. Putney Jr., Capacitative calcium entry revisited, Cell Calcium 11 (1990) 611-624.

[17] I.M. Manjarres, M.T. Alonso, J. Garcia-Sancho, Calcium entry-calcium refilling (CECR) coupling between store-operated $\mathrm{Ca}(2+)$ entry and sarco/endoplasmic reticulum $\mathrm{Ca}(2+)$-ATPase, Cell Calcium 49 (2011) 153-161.

[18] I.M. Manjarres, A. Rodriguez-Garcia, M.T. Alonso, J. Garcia-Sancho, The sarco/endoplasmic reticulum $\mathrm{Ca}(2+)$ ATPase (SERCA) is the third element in capacitative calcium entry, Cell Calcium 47 (2010) 412-418.

[19] R. Penner, G. Matthews, E. Neher, Regulation of calcium influx by second messengers in rat mast cells, Nature 334 (1988) 499-504.

[20] A.F. Fomina, E.S. Levitan, Three phases of TRH-induced facilitation of exocytosis by single lactotrophs, J. Neurosci. 15 (1995) 4982-4991.

[21] Y.X. Li, S.S. Stojilkovic, J. Keizer, J. Rinzel, Sensing and refilling calcium stores in an excitable cell, Biophys. J. 72 (1997) 1080-1091.

[22] M.T. Alonso, M.J. Barrero, P. Michelena, E. Carnicero, I. Cuchillo, A.G. Garcia, J. Garcia-Sancho, M. Montero, J. Alvarez, $\mathrm{Ca}^{2+}$-induced $\mathrm{Ca}^{2+}$ release in chromaffin cells seen from inside the ER with targeted aequorin, J. Cell Biol. 144 (1999) 241-254.

[23] I.M. Robinson, T.R. Cheek, R.D. Burgoyne, $\mathrm{Ca}^{2+}$ influx induced by the $\mathrm{Ca}(2+)-$ ATPase inhibitors 2,5-di-(t-butyl)-1,4-benzohydroquinone and thapsigargin in bovine adrenal chromaffin cells, Biochem. J. 288 (Pt 2) (1992) 457-463.

[24] T.R. Cheek, A. Morgan, A.J. O'Sullivan, R.B. Moreton, M.J. Berridge, R.D. Burgoyne, Spatial localization of agonist-induced $\mathrm{Ca}^{2+}$ entry in bovine adrenal 
chromaffin cells. Different patterns induced by histamine and angiotensin II, and relationship to catecholamine release, J. Cell Sci. 105 (Pt 4) (1993) 913-921.

[25] T.R. Cheek, M.M. Murawsky, K.A. Stauderman, Histamine-induced $\mathrm{Ca}^{2+}$ entry precedes $\mathrm{Ca}^{2+}$ mobilization in bovine adrenal chromaffin cells, Biochem. J. 304 (Pt 2) (1994) 469-476.

[26] D.A. Powis, C.L. Clark, K.J. O’Brien, Depleted internal store-activated $\mathrm{Ca}^{2+}$ entry can trigger neurotransmitter release in bovine chromaffin cells, Neurosci. Lett. 204 (1996) 165-168.

[27] A.G. Teschemacher, E.P. Seward, Bidirectional modulation of exocytosis by angiotensin II involves multiple G-protein-regulated transduction pathways in chromaffin cells, J. Neurosci. 20 (2000) 4776-4785.

[28] M. Zerbes, C.L. Clark, D.A. Powis, Neurotransmitter release from bovine adrenal chromaffin cells is modulated by capacitative $\mathrm{Ca}(2+)$ entry driven by depleted internal $\mathrm{Ca}(2+)$ stores, Cell Calcium 29 (2001) 49-58.

[29] A.F. Fomina, M.C. Nowycky, A current activated on depletion of intracellular $\mathrm{Ca}^{2+}$ stores can regulate exocytosis in adrenal chromaffin cells, J. Neurosci. 19 (1999) 3711-3722.

[30] M.Zerbes, S.J. Bunn, D.A. Powis, Histamine causes $\mathrm{Ca}^{2+}$ entry via both a storeoperated and a store-independent pathway in bovine adrenal chromaffin cells, Cell Calcium 23 (1998) 379-386.

[31] I.M. Robinson, M. Yamada, M. Carrion-Vazquez, V.A. Lennon, J.M. Fernandez, Specialized release zones in chromaffin cells examined with pulsed-laser imaging, Cell Calcium 20 (1996) 181-201.

[32] G.J. Augustine, E. Neher, Calcium requirements for secretion in bovine chromaffin cells, J. Physiol. 450 (1992) 247-271.

[33] A.R. Artalejo, A.G. Garcia, E. Neher, Small-conductance $\mathrm{Ca}(2+)$-activated $\mathrm{K}^{+}$ channels in bovine chromaffin cells, Pflugers Arch. 423 (1993) 97-103.

[34] M. Rogers, J.A. Dani, Comparison of quantitative calcium flux through NMDA, ATP, and ACh receptor channels, Biophys. J. 68 (1995) 501-506.

[35] R. Schneggenburger, Z. Zhou, A. Konnerth, E. Neher, Fractional contribution of calcium to the cation current through glutamate receptor channels, Neuron 11 (1993) 133-143.

[36] Z. Zhou, E. Neher, Calcium permeability of nicotinic acetylcholine receptor channels in bovine adrenal chromaffin cells, Pflugers Arch. 425 (1993) 511-517.

[37] J.J. Arnaiz-Cot, A.M. de Diego, J.M. Hernandez-Guijo, L. Gandia, A.G. Garcia, A two-step model for acetylcholine control of exocytosis via nicotinic receptors, Biochem. Biophys. Res. Commun. 365 (2008) 413-419.

[38] A.M. de Diego, L. Tapia, R.M. Alvarez, M. Mosquera, L. Cortes, I. Lopez, L.M. Gutierrez, L. Gandia, A.G. Garcia, A low nicotine concentration augments vesicle motion and exocytosis triggered by $\mathrm{K}(+)$ depolarisation of chromaffin cells, Eur. J. Pharmacol. 598 (2008) 81-86.

[39] M.P. Gonzalez, M.T. Herrero, S. Vicente, M.J. Oset-Gasque, Effect of glutamate receptor agonists on catecholamine secretion in bovine chromaffin cells, Neuroendocrinology 67 (1998) 181-189.

[40] E. Castro, A.R. Tome, M.T. Miras-Portugal, L.M. Rosario, Single-cell fura2 microfluorometry reveals different purinoceptor subtypes coupled to $\mathrm{Ca}^{2+}$ influx and intracellular $\mathrm{Ca}^{2+}$ release in bovine adrenal chromaffin and endothelial cells, Pflugers Arch. 426 (1994) 524-533.

[41] M. Liu, P.M. Dunn, B.F. King, G. Burnstock, Rat chromaffin cells lack P2X receptors while those of the guinea-pig express a P2X receptor with novel pharmacology, Br. J. Pharmacol. 128 (1999) 61-68.

[42] A.R. Tome, E. Castro, R.M. Santos, L.M. Rosario, Selective stimulation of catecholamine release from bovine adrenal chromaffin cells by an ionotropic purinergic receptor sensitive to 2-methylthio ATP, BMC Neurosci. 8 (2007) 41.

[43] A.R. Tome, E. Castro, R.M. Santos, L.M. Rosario, Functional distribution of $\mathrm{Ca}^{2+}$ coupled P2 purinergic receptors among adrenergic and noradrenergic bovine adrenal chromaffin cells, BMC Neurosci. 8 (2007) 39.

[44] M. Diverse-Pierluissi, K. Dunlap, E.W. Westhead, Multiple actions of extracellular ATP on calcium currents in cultured bovine chromaffin cells, Proc. Natl. Acad. Sci. U.S.A. 88 (1991) 1261-1265.

[45] L. Gandia, A. Albillos, A.G. Garcia, Bovine chromaffin cells possess FTXsensitive calcium channels, Biochem. Biophys. Res. Commun. 194 (1993) 671-676.

[46] E. Castro, M.P. Gonzalez, M.J. Oset-Gasque, Distribution of gammaaminobutyric acid receptors in cultured adrenergic and noradrenergic bovine chromaffin cells, J. Neurosci. Res. 71 (2003) 375-382.

[47] Z. Xie, K.P. Currie, A.L. Cahill, A.P. Fox, Role of $\mathrm{Cl}^{-}$co-transporters in the excitation produced by GABAA receptors in juvenile bovine adrenal chromaffin cells, J. Neurophysiol. 90 (2003) 3828-3837.

[48] Z. Xie, K.P. Currie, A.P. Fox, Etomidate elevates intracellular calcium levels and promotes catecholamine secretion in bovine chromaffin cells, J. Physiol. 560 (2004) 677-690.

[49] H. Matsuoka, K. Harada, Y. Endo, A. Warashina, Y. Doi, J. Nakamura, M. Inoue, Molecular mechanisms supporting a paracrine role of GABA in rat adrenal medullary cells, J. Physiol. 586 (2008) 4825-4842.

[50] S.H. Lee, B. Schwaller, E. Neher, Kinetics of $\mathrm{Ca}^{2+}$ binding to parvalbumin in bovine chromaffin cells: implications for $\left[\mathrm{Ca}^{2+}\right]$ transients of neuronal dendrites, J. Physiol. 525 (Pt 2) (2000) 419-432.

[51] E. Ales, M. Cano-Abad, A.G. Garcia, M.G. Lopez, Different cellular distribution of calbindin D28k: implications for the cytosolic $\mathrm{Ca}(2+)$ and exocytotic signals in single bovine and mouse chromaffin cells, Ann. N.Y. Acad. Sci. 971 (2002) 168-170.
[52] M.T. Alonso, J. Garcia-Sancho, Nuclear $\mathrm{Ca}(2+)$ signalling, Cell Calcium 49 (2011) 280-289.

[53] M. Naraghi, T.H. Muller, E. Neher, Two-dimensional determination of the cellular $\mathrm{Ca}^{2+}$ binding in bovine chromaffin cells, Biophys. J. 75 (1998) 1635-1647.

[54] P. Chamero, C. Villalobos, M.T. Alonso, J. Garcia-Sancho, Dampening of cytosolic $\mathrm{Ca}^{2+}$ oscillations on propagation to nucleus, J. Biol. Chem. 277 (2002) 50226-50229.

[55] O. Gerasimenko, J. Gerasimenko, New aspects of nuclear calcium signalling, J. Cell Sci. 117 (2004) 3087-3094.

[56] M.N. Teruel, W. Chen, A. Persechini, T. Meyer, Differential codes for free $\mathrm{Ca}(2+)$-calmodulin signals in nucleus and cytosol, Curr. Biol. 10 (2000) 86-94.

[57] P. Chamero, I.M. Manjarres, J.M. Garcia-Verdugo, C. Villalobos, M.T. Alonso, J. Garcia-Sancho, Nuclear calcium signaling by inositol trisphosphate in GH3 pituitary cells, Cell Calcium 43 (2008) 205-214.

[58] H. Winkler, E. Westhead, The molecular organization of adrenal chromaffin granules, Neuroscience 5 (1980) 1803-1823.

[59] D. Bulenda, M. Gratzl, Matrix free $\mathrm{Ca}^{2+}$ in isolated chromaffin vesicles, Biochemistry 24 (1985) 7760-7765.

[60] J. Santodomingo, L. Vay, M. Camacho, E. Hernandez-Sanmiguel, R.I. Fonteriz, C.D. Lobaton, M. Montero, A. Moreno, J. Alvarez, Calcium dynamics in bovine adrenal medulla chromaffin cell secretory granules, Eur. J. Neurosci. 28 (2008) 1265-1274.

[61] S.H. Yoo, J.P. Albanesi, High capacity, low affinity $\mathrm{Ca}^{2+}$ binding of chromogranin A. Relationship between the $\mathrm{pH}$-induced conformational change and $\mathrm{Ca}^{2+}$ binding property, J. Biol. Chem. 266 (1991) 7740-7745.

[62] M.L. Mundorf, S.E. Hochstetler, R.M. Wightman, Amine weak bases disrupt vesicular storage and promote exocytosis in chromaffin cells, J. Neurochem. 73 (1999) 2397-2405.

[63] M.L. Mundorf, K.P. Troyer, S.E. Hochstetler, J.A. Near, R.M. Wightman, Vesicular $\mathrm{Ca}(2+)$ participates in the catalysis of exocytosis, J. Biol. Chem. 275 (2000) 9136-9142.

[64] A. Moreno, C.D. Lobaton, J. Santodomingo, L. Vay, E. Hernandez-SanMiguel, R. Rizzuto, M. Montero, J. Alvarez, Calcium dynamics in catecholaminecontaining secretory vesicles, Cell Calcium 37 (2005) 555-564.

[65] M. Camacho, J.D. Machado, M.S. Montesinos, M. Criado, R. Borges, Intragranular pH rapidly modulates exocytosis in adrenal chromaffin cells, J. Neurochem. 96 (2006) 324-334.

[66] C.L. Haynes, L.A. Buhler, R.M. Wightman, Vesicular Ca(2+)-induced secretion promoted by intracellular pH-gradient disruption, Biophys. Chem. 123 (2006) 20-24.

[67] H. Plattner, A.R. Artalejo, E. Neher, Ultrastructural organization of bovine chromaffin cell cortex-analysis by cryofixation and morphometry of aspects pertinent to exocytosis, J. Cell Biol. 139 (1997) 1709-1717.

[68] J.R. Haigh, R. Parris, J.H. Phillips, Free concentrations of sodium, potassium and calcium in chromaffin granules, Biochem. J. 259 (1989) 485-491

[69] J.L. Borowitz, Calcium binding by subcellular fractions of bovine adrenal medulla, J. Cell. Physiol. 69 (1967) 311-319.

[70] S.H. Yoo, pH-dependent interaction of chromogranin A with integral membrane proteins of secretory vesicle including $260-\mathrm{kDa}$ protein reactive to inositol 1,4,5-triphosphate receptor antibody, J. Biol. Chem. 269 (1994) $12001-12006$

[71] S.H. Yoo, S.W. Nam, S.K. Huh, S.Y. Park, Y.H. Huh, Presence of a nucleoplasmic complex composed of the inositol 1,4,5-trisphosphate receptor $/ \mathrm{Ca}^{2+}$ channel, chromogranin B, and phospholipids, Biochemistry 44 (2005) 9246-9254.

[72] S.H. Yoo, J.P. Albanesi, Ca2(+)-induced conformational change and aggregation of chromogranin A, J. Biol. Chem. 265 (1990) 14414-14421.

[73] Y.H. Huh, S.Y. Chu, S.Y. Park, S.K. Huh, S.H. Yoo, Role of nuclear chromogranin B in inositol 1,4,5-trisphosphate-mediated nuclear $\mathrm{Ca}^{2+}$ mobilization, Biochemistry 45 (2006) 1212-1226.

[74] J.D. Machado, M. Camacho, J. Alvarez, R. Borges, On the role of intravesicular calcium in the motion and exocytosis of secretory organelles, Commun. Integr. Biol. 2 (2009) 71-73.

[75] S.H. Yoo, Y.H. Huh, Y.S. Hur, Inositol 1,4,5-trisphosphate receptor in chromaffin secretory granules and its relation to chromogranins, Cell. Mol. Neurobiol. 30 (2010) 1155-1161.

[76] S. Ebashi, F. Lipmann, Adenosine triphosphate-linked concentration of calcium ions in a particulate fraction of rabbit muscle, J. Cell Biol. 14 (1962) 389-400.

[77] W. Hasselbach, M. Makinose, ATP and active transport, Biochem. Biophys. Res. Commun. 7 (1962) 132-136.

[78] E. Carafoli, Intracellular calcium homeostasis, Annu. Rev. Biochem. 56 (1987) 395-433.

[79] M.J. Berridge, Neuronal calcium signaling, Neuron 21 (1998) 13-26.

[80] E.P. Noble, M. Bommer, E. Sincini, T. Costa, A. Herz, H1-histaminergic activation stimulates inositol-1-phosphate accumulation in chromaffin cells, Biochem. Biophys. Res. Commun. 135 (1986) 566-573.

[81] R. Plevin, M.R. Boarder, Stimulation of formation of inositol phosphates in primary cultures of bovine adrenal chromaffin cells by angiotensin II, histamine, bradykinin, and carbachol, J. Neurochem. 51 (1988) 634-641.

[82] N. Sasakawa, T. Nakaki, R. Kato, Formation of inositol polyphosphates in cultured adrenal chromaffin cells, Adv. Exp. Med. Biol. 287 (1991) 111-123.

[83] K.A. Stauderman, R.M. Pruss, Different patterns of agonist-stimulated increases of $3 \mathrm{H}$-inositol phosphate isomers and cytosolic $\mathrm{Ca}^{2+}$ in bovine adrenal chromaffin cells: comparison of the effects of histamine and angiotensin II, J. Neurochem. 54 (1990) 946-953. 
[84] K.A. Stauderman, R.A. McKinney, M.M. Murawsky, The role of caffeinesensitive $\mathrm{Ca}^{2+}$ stores in agonist- and inositol 1,4,5-trisphosphate-induced $\mathrm{Ca}^{2+}$ release from bovine adrenal chromaffin cells, Biochem. J. 278 (Pt 3) (1991) 643-650.

[85] K.A. Stauderman, M.M. Murawsky, The inositol 1,4,5-trisphosphate-forming agonist histamine activates a ryanodine-sensitive $\mathrm{Ca}^{2+}$ release mechanism in bovine adrenal chromaffin cells, J. Biol. Chem. 266 (1991) 19150-19153.

[86] K. Tanaka, I. Shibuya, T. Nagamoto, H. Yamashita, T. Kanno, Pituitary adenylate cyclase-activating polypeptide causes rapid $\mathrm{Ca}^{2+}$ release from intracellular stores and long lasting $\mathrm{Ca}^{2+}$ influx mediated by $\mathrm{Na}^{+}$influx-dependent membrane depolarization in bovine adrenal chromaffin cells, Endocrinology 137 (1996) 956-966.

[87] P. D'Andrea, F. Grohovaz, $\left[\mathrm{Ca}^{2+}\right]_{\mathrm{i}}$ oscillations in rat chromaffin cells: frequency and amplitude modulation by $\mathrm{Ca}^{2+}$ and $\mathrm{InsP}_{3}$, Cell Calcium 17 (1995)367-374.

[88] P. D'Andrea, P. Thorn, $\mathrm{Ca}^{2+}$ signalling in rat chromaffin cells: interplay between $\mathrm{Ca}^{2+}$ release from intracellular stores and membrane potential, Cell Calcium 19 (1996) 113-123.

[89] T. Ohta, S. Ito, Y. Nakazato, $\mathrm{Ca}^{2+}$-dependent $\mathrm{K}^{+}$currents induced by muscarinic receptor activation in guinea pig adrenal chromaffin cells, J. Neurochem. 70 (1998) 1280-1288.

[90] G. Uceda, A.R. Artalejo, M.G. Lopez, F. Abad, E. Neher, A.G. Garcia, Ca(2+) activated $\mathrm{K}^{+}$channels modulate muscarinic secretion in cat chromaffin cells, J. Physiol. 454 (1992) 213-230.

[91] G. Uceda, A.R. Artalejo, M.T. de la Fuente, M.G. Lopez, A. Albillos, P. Michelena, A.G. Garcia, C. Montiel, Modulation by L-type $\mathrm{Ca}^{2+}$ channels and apaminsensitive $\mathrm{K}^{+}$channels of muscarinic responses in cat chromaffin cells, Am. J. Physiol. 266 (1994) C1432-C1439.

[92] B. Lara, P. Zapater, C. Montiel, M.T. de la Fuente, R. Martinez-Sierra, J.J. Ballesta, L. Gandia, A.G. Garcia, Density of apamin-sensitive $\mathrm{Ca}(2+)$-dependent $\mathrm{K}^{+}$channels in bovine chromaffin cells: relevance to secretion, Biochem. Pharmacol. 49 (1995) 1459-1468.

[93] S.J. Bunn, T.L. Boyd, Characterization of histamine-induced catecholamine secretion from bovine adrenal medullary chromaffin cells, J. Neurochem. 58 (1992) 1602-1610.

[94] B.G. Livett, P.D. Marley, Effects of opioid peptides and morphine on histamineinduced catecholamine secretion from cultured, bovine adrenal chromaffin cells, Br. J. Pharmacol. 89 (1986) 327-334.

[95] E.P. Noble, M. Bommer, D. Liebisch, A. Herz, H1-histaminergic activation of catecholamine release by chromaffin cells, Biochem. Pharmacol. 37 (1988) 221-228.

[96] A.J. O’Sullivan, T.R. Cheek, R.B. Moreton, M.J. Berridge, R.D. Burgoyne, Localization and heterogeneity of agonist-induced changes in cytosolic calcium concentration in single bovine adrenal chromaffin cells from video imaging of fura-2, EMBO J. 8 (1989) 401-411.

[97] M. Bodding, Histamine evoked sustained elevations of cytosolic $\mathrm{Ca}^{2+}$ in bovine adrenal chromaffin cells independently of $\mathrm{Ca}^{2+}$ entry, Cell Calcium 27 (2000) 139-151.

[98] D.J. Wallace, C. Chen, P.D. Marley, Histamine promotes excitability in bovine adrenal chromaffin cells by inhibiting an M-current, J. Physiol. 540 (2002) 921-939.

[99] L. von Ruden, E. Neher, A Ca-dependent early step in the release of catecholamines from adrenal chromaffin cells, Science 262 (1993) 1061-1065.

[100] K.A. Stauderman, M.M. Murawsky, R.M. Pruss, Agonist-dependent patterns of cytosolic $\mathrm{Ca}^{2+}$ changes in single bovine adrenal chromaffin cells: relationship to catecholamine release, Cell Regul. 1 (1990) 683-691.

[101] T.R. Cheek, O. Thastrup, Internal $\mathrm{Ca}^{2+}$ mobilization and secretion in bovine adrenal chromaffin cells, Cell Calcium 10 (1989) 213-221.

[102] T.R. Cheek, A.J. O'Sullivan, R.B. Moreton, M.J. Berridge, R.D. Burgoyne, The caffeine-sensitive $\mathrm{Ca}^{2+}$ store in bovine adrenal chromaffin cells: an examination of its role in triggering secretion and $\mathrm{Ca}^{2+}$ homeostasis, FEBS Lett. 266 (1990) 91-95.

[103] T.R. Cheek, R.B. Moreton, M.J. Berridge, K.A. Stauderman, M.M. Murawsky, M.D. Bootman, Quantal $\mathrm{Ca}^{2+}$ release from caffeine-sensitive stores in adrenal chromaffin cells, J. Biol. Chem. 268 (1993) 27076-27083.

[104] T.R. Cheek, M.J. Berridge, R.B. Moreton, K.A. Stauderman, M.M. Murawsky, M.D. Bootman, Quantal $\mathrm{Ca}^{2+}$ mobilization by ryanodine receptors is due to all-or-none release from functionally discrete intracellular stores, Biochem. J. 301 (Pt 3) (1994) 879-883.

[105] T.R. Cheek, V.A. Barry, M.J. Berridge, L. Missiaen, Bovine adrenal chromaffin cells contain an inositol 1,4,5-trisphosphate-insensitive but caffeinesensitive $\mathrm{Ca}^{2+}$ store that can be regulated by intraluminal free $\mathrm{Ca}^{2+}$, Biochem. J. 275 (Pt 3) (1991) 697-701.

[106] P.S. Liu, Y.J. Lin, L.S. Kao, Caffeine-sensitive calcium stores in bovine adrenal chromaffin cells, J. Neurochem. 56 (1991) 172-177.

[107] I.M. Robinson, R.D. Burgoyne, Characterisation of distinct inositol 1,4,5trisphosphate-sensitive and caffeine-sensitive calcium stores in digitoninpermeabilised adrenal chromaffin cells, J. Neurochem. 56 (1991) 1587-1593.

[108] K. Morita, S. Kitayama, T. Dohi, Stimulation of cyclic ADP-ribose synthesis by acetylcholine and its role in catecholamine release in bovine adrenal chromaffin cells, J. Biol. Chem. 272 (1997) 21002-21009.

[109] C. Villalobos, L. Nunez, M. Montero, A.G. Garcia, M.T. Alonso, P. Chamero, J. Alvarez, J. Garcia-Sancho, Redistribution of $\mathrm{Ca}^{2+}$ among cytosol and organella during stimulation of bovine chromaffin cells, FASEB J. 16 (2002) 343-353.

[110] R. Rigual, M. Montero, A.J. Rico, J. Prieto-Lloret, M.T. Alonso, J. Alvarez, Modulation of secretion by the endoplasmic reticulum in mouse chromaffin cells, Eur. J. Neurosci. 16 (2002) 1690-1696.
[111] P.C. Wu, M.J. Fann, L.S. Kao, Characterization of $\mathrm{Ca}^{2+}$ signaling pathways in mouse adrenal medullary chromaffin cells, J. Neurochem. 112 (2010) $1210-1222$

[112] H. Teraoka, Y. Nakazato, A. Ohga, Ryanodine inhibits caffeine-evoked $\mathrm{Ca}^{2+}$ mobilization and catecholamine secretion from cultured bovine adrenal chromaffin cells, J. Neurochem. 57 (1991) 1884-1890.

[113] B. Lara, M.G. Lopez, M. Villarroya, L. Gandia, L. Cleeman, M. Morad, A.G. Garcia A caffeine-sensitive $\mathrm{Ca}^{2+}$ store modulates $\mathrm{K}^{+}$-evoked secretion in chromaffin cells, Am. J. Physiol. 272 (1997) C1211-C1221.

[114] P. Mollard, E.P. Seward, M.C. Nowycky, Activation of nicotinic receptors triggers exocytosis from bovine chromaffin cells in the absence of membrane depolarization, Proc. Natl. Acad. Sci. U.S.A. 92 (1995) 3065-3069.

[115] C.Y. Pan, A.P. Fox, Rundown of secretion after depletion of intracellular calcium stores in bovine adrenal chromaffin cells, J. Neurochem. 75 (2000) 1132-1139.

[116] I. Cuchillo-Ibanez, R. Olivares, M. Aldea, M. Villarroya, G. Arroyo, J. Fuentealba, A.G. Garcia, A. Albillos, Acetylcholine and potassium elicit different patterns of exocytosis in chromaffin cells when the intracellular calcium handling is disturbed, Pflugers Arch. 444 (2002) 133-142.

[117] A.M. de Diego, Electrophysiological and morphological features underlying neurotransmission efficacy at the splanchnic nerve-chromaffin cell synapse of bovine adrenal medulla, Am. J. Physiol. Cell Physiol 298 (2010) C397-C405.

[118] C. Orozco, A.M. Garcia-de-Diego, E. Arias, J.M. Hernandez-Guijo, A.G. Garcia, M. Villarroya, M.G. Lopez, Depolarization preconditioning produces cytoprotection against veratridine-induced chromaffin cell death, Eur. J. Pharmacol. 553 (2006) 28-38.

[119] M.R. Duchen, Mitochondria and $\mathrm{Ca}(2+)$ in cell physiology and pathophysiology, Cell Calcium 28 (2000) 339-348.

[120] M.R. Duchen, G. Szabadkai, Roles of mitochondria in human disease, Essays Biochem. 47 (2010) 115-137.

121] B. Reynafarje, A.L. Lehninger, Electric charge stoichiometry of calcium translocation in mitochondria, Biochem. Biophys. Res. Commun. 77 (1977) 1273-1279.

[122] E. Carafoli, The calcium cycle of mitochondria, FEBS Lett. 104 (1979) 1-5

[123] T.E. Gunter, D.R. Pfeiffer, Mechanisms by which mitochondria transport calcium, Am. J. Physiol. 258 (1990) C755-C786.

[124] M. Montero, M.T. Alonso, A. Albillos, J. Garcia-Sancho, J. Alvarez, Mitochondrial $\mathrm{Ca}(2+)$-induced $\mathrm{Ca}(2+)$ release mediated by the $\mathrm{Ca}(2+)$ uniporter, Mol. Biol. Cell 12 (2001) 63-71.

[125] R. Rizzuto, M. Brini, M. Murgia, T. Pozzan, Microdomains with high $\mathrm{Ca}^{2+}$ close to IP3-sensitive channels that are sensed by neighboring mitochondria, Science 262 (1993) 744-747.

[126] D.F. Babcock, J. Herrington, P.C. Goodwin, Y.B. Park, B. Hille, Mitochondrial participation in the intracellular $\mathrm{Ca}^{2+}$ network, J. Cell Biol. 136 (1997) 833-844.

[127] Y.B. Park, J. Herrington, D.F. Babcock, B. Hille, $\mathrm{Ca}^{2+}$ clearance mechanisms in isolated rat adrenal chromaffin cells, J. Physiol. 492 (Pt 2) (1996) 329-346.

[128] T. Xu, M. Naraghi, H. Kang, E. Neher, Kinetic studies of $\mathrm{Ca}^{2+}$ binding and $\mathrm{Ca}^{2+}$ clearance in the cytosol of adrenal chromaffin cells, Biophys. J. 73 (1997) 532-545.

[129] M.T. Alonso, C. Villalobos, P. Chamero, J. Alvarez, J. Garcia-Sancho, Calcium microdomains in mitochondria and nucleus, Cell Calcium 40 (2006) 513-525.

[130] M. Montero, M.T. Alonso, E. Carnicero, I. Cuchillo-Ibanez, A. Albillos, A.G. Garcia, J. Garcia-Sancho, J. Alvarez, Chromaffin-cell stimulation triggers fast millimolar mitochondrial $\mathrm{Ca}^{2+}$ transients that modulate secretion, Nat. Cell Biol. 2 (2000) 57-61.

[131] D.M. Yang, L.S. Kao, Relative contribution of the $\mathrm{Na}(+) / \mathrm{Ca}(2+)$ exchanger, mitochondria and endoplasmic reticulum in the regulation of cytosolic $\mathrm{Ca}(2+)$ and catecholamine secretion of bovine adrenal chromaffin cells, J. Neurochem. 76 (2001) 210-216.

[132] D.R. Giovannucci, M.D. Hlubek, E.L. Stuenkel, Mitochondria regulate the $\mathrm{Ca}(2+)$-exocytosis relationship of bovine adrenal chromaffin cells, J. Neurosci. 19 (1999) 9261-9270.

[133] I. Cuchillo-Ibanez, T. Lejen, A. Albillos, S.D. Rose, R. Olivares, M. Villarroya, A.G Garcia, J.M. Trifaro, Mitochondrial calcium sequestration and protein kinase $\mathrm{C}$ cooperate in the regulation of cortical F-actin disassembly and secretion in bovine chromaffin cells, J. Physiol. 560 (2004) 63-76.

[134] M. Montero, M.T. Alonso, A. Albillos, I. Cuchillo-Ibanez, R. Olivares, A. GG, J. Garcia-Sancho, J. Alvarez, Control of secretion by mitochondria depends on the size of the local $\left[\mathrm{Ca}^{2+}\right]$ after chromaffin cell stimulation, Eur. J. Neurosci. 13 (2001) 2247-2254

[135] E. Ales, J. Fuentealba, A.G. Garcia, M.G. Lopez, Depolarization evokes different patterns of calcium signals and exocytosis in bovine and mouse chromaffin cells: the role of mitochondria, Eur. J. Neurosci. 21 (2005) 142-150.

[136] J.M. Hernandez-Guijo, V.E. Maneu-Flores, A. Ruiz-Nuno, M. Villarroya, A.G Garcia, L. Gandia, Calcium-dependent inhibition of L, N, and P/Q Ca ${ }^{2+}$ channels in chromaffin cells: role of mitochondria, J. Neurosci. 21 (2001) 2553-2560.

[137] L.S. Kao, N.S. Cheung, Mechanism of calcium transport across the plasma membrane of bovine chromaffin cells, J. Neurochem. 54 (1990) 1972-1979.

[138] J.M. Salvador, G. Inesi, J.L. Rigaud, A.M. Mata, $\mathrm{Ca}^{2+}$ transport by reconstituted synaptosomal ATPase is associated with $\mathrm{H}^{+}$countertransport and net charge displacement, J. Biol. Chem. 273 (1998) 18230-18234.

[139] P.F. Baker, M.P. Blaustein, A.L. Hodgkin, R.A. Steinhardt, The influence of calcium on $\mathrm{Na}^{+}$efflux in Squid axons, J. Physiol. 200 (1969) 431-458. 
[140] M.P. Blaustein, W.J. Lederer, Sodium/calcium exchange: its physiological implications, Physiol. Rev. 79 (1999) 763-854.

[141] L. Annunziato, G. Pignataro, G.F. Di Renzo, Pharmacology of brain $\mathrm{Na}^{+} / \mathrm{Ca}^{2+}$ exchanger: from molecular biology to therapeutic perspectives, Pharmacol. Rev. 56 (2004) 633-654

[142] C.Y. Pan, L.S. Kao, Catecholamine secretion from bovine adrenal chromaffin cells: the role of the $\mathrm{Na}^{+} / \mathrm{Ca}^{2+}$ exchanger and the intracellular $\mathrm{Ca}^{2+}$ pool, $\mathrm{J}$. Neurochem. 69 (1997) 1085-1092.

[143] P.S. Liu, L.S. Kao, $\mathrm{Na}(+)$-dependent $\mathrm{Ca}^{2+}$ influx in bovine adrenal chromaffin cells, Cell Calcium 11 (1990) 573-579.

[144] D.A. Powis, K.J. O’Brien, H.R. Von Grafenstein, Calcium export by sodium-calcium exchange in bovine chromaffin cells, Cell Calcium 12 (1991) 493-504.

[145] J.C. Skou, The influence of some cations on an adenosine triphosphatase from peripheral nerves, Biochim. Biophys. Acta 23 (1957) 394-401.

[146] M.P. Blaustein, Physiological effects of endogenous ouabain: control of intracellular $\mathrm{Ca}^{2+}$ stores and cell responsiveness, Am. J. Physiol. 264 (1993) C1367-C1387.

[147] P. Banks, The effect of ouabain on the secretion of catecholamines and on the intracellular concentration of potassium, J. Physiol. 193 (1967) 631-637.

[148] D. Aunis, A.G. Garcia, Correlation between catecholamine secretion from bovine isolated chromaffin cells and $[3 \mathrm{H}]$-ouabain binding to plasma membranes, Br. J. Pharmacol. 72 (1981) 31-40.

[149] A.G. Garcia, M. Hernandez, J.F. Horga, P. Sanchez-Garcia, On the release of catecholamines and dopamine-beta-hydroxylase evoked by ouabain in the perfused cat adrenal gland, Br. J. Pharmacol. 68 (1980) 571-583.

[150] E. Esquerro, A.G. Garcia, M. Herandez, S.M. Kirpekar, J.C. Prat, Catecholamine secretory response to calcium reintroduction in the perfused cat adrenal gland treated with ouabain, Biochem. Pharmacol. 29 (1980) 2669-2673.

[151] R. de Pascual, A.G. Garcia, Ouabain augments and maintains the catecholamine release responses evoked by repetitive pulses of potassium, caffeine or histamine in perifused bovine chromaffin cells, Eur. J. Pharmacol. 568 (2007) 99-105.

[152] J. Milla, M.S. Montesinos, J.D. Machado, R. Borges, E. Alonso, A.J. MorenoOrtega, M.F. Cano-Abad, A.G. Garcia, A. Ruiz-Nuno, Ouabain enhances exocytosis through the regulation of calcium handling by the endoplasmic reticulum of chromaffin cells, Cell Calcium 50 (2011) 332-342.

[153] Y.J. Chern, S.H. Chueh, Y.J. Lin, C.M. Ho, L.S. Kao, Presence of $\mathrm{Na}^{+} / \mathrm{Ca}^{2+}$ exchange activity and its role in regulation of intracellular calcium concentration in bovine adrenal chromaffin cells, Cell Calcium 13 (1992) 99-106.

[154] M.T. De la Fuente, R. Maroto, E. Esquerro, P. Sanchez-Garcia, A.G. Garcia, The actions of ouabain and lithium chloride on cytosolic $\mathrm{Ca}^{2+}$ in single chromaffin cells, Eur. J. Pharmacol. 306 (1996) 219-226.

[155] M. Juhaszova, M.P. Blaustein, $\mathrm{Na}^{+}$pump low and high ouabain affinity alpha subunit isoforms are differently distributed in cells, Proc. Natl. Acad. Sci. U.S.A. 94 (1997) 1800-1805.

[156] J. Liu, S.M. Periyasamy, W. Gunning, O.V. Fedorova, A.Y. Bagrov, D. Malhotra, Z. Xie, J.I. Shapiro, Effects of cardiac glycosides on sodium pump expression and function in LLC-PK1 and MDCK cells, Kidney Int. 62 (2002) 2118-2125.

[157] J.M. Hamlyn, M.P. Blaustein, S. Bova, D.W. DuCharme, D.W. Harris, F. Mandel, W.R. Mathews, J.H. Ludens, Identification and characterization of a ouabainlike compound from human plasma, Proc. Natl. Acad. Sci. U.S.A. 88 (1991) 6259-6263.

[158] A. Kawamura, J. Guo, Y. Itagaki, C. Bell, Y. Wang, G.T. Haupert Jr., S. Magil, R.T. Gallagher, N. Berova, K. Nakanishi, On the structure of endogenous ouabain, Proc. Natl. Acad. Sci. U.S.A. 96 (1999) 6654-6659.

[159] S. Li, C. Eim, U. Kirch, R.E. Lang, W. Schoner, Bovine adrenals and hypothalamus are a major source of proscillaridin A- and ouabain-immunoreactivities, Life Sci. 62 (1998) 1023-1033.

[160] C.Y. Pan, Y.S. Chu, L.S. Kao, Molecular study of the $\mathrm{Na}^{+} / \mathrm{Ca}^{2+}$ exchanger in bovine adrenal chromaffin cells, Biochem. J. 336 (Pt 2) (1998) 305-310.

[161] A.G. Garcia, E. Garcia-Lopez, J.F. Horga, S.M. Kirpekar, C. Montiel, P. SanchezGarcia, Potentiation of $\mathrm{K}^{+}$-evoked catecholamine release in the cat adrenal gland treated with ouabain, Br. J. Pharmacol. 74 (1981) 673-680.

[162] A.G. Garcia, E. Garcia-Lopez, C. Montiel, G.P. Nicolas, P. Sanchez-Garcia, Correlation between catecholamine release and sodium pump inhibition in the perfused adrenal gland of the cat, Br. J. Pharmacol. 74 (1981) 665-672.

[163] T.J. Rink, The influence of sodium on calcium movements and catecholamine release in thin slices of bovine adrenal medulla, J. Physiol. 266 (1977) 297-325.

[164] L.F. Lin, L.S. Kao, E.W. Westhead, Agents that promote protein phosphorylation inhibit the activity of the $\mathrm{Na}^{+} / \mathrm{Ca}^{2+}$ exchanger and prolong $\mathrm{Ca}^{2+}$ transients in bovine chromaffin cells, J. Neurochem. 63 (1994) 1941-1947.

[165] C.Y. Pan, C.H. Huang, C.H. Lee, Calcium elevation elicited by reverse mode $\mathrm{Na}^{+} / \mathrm{Ca}^{2+}$ exchange activity is facilitated by intracellular calcium stores in bovine chromaffin cells, Biochem. Biophys. Res. Commun. 342 (2006) 589-595.

[166] C.Y. Pan, L.L. Tsai, J.H. Jiang, L.W. Chen, L.S. Kao, The co-presence of $\mathrm{Na}^{+} / \mathrm{Ca}^{2+}-\mathrm{K}^{+}$exchanger and $\mathrm{Na}^{+} / \mathrm{Ca}^{2+}$ exchanger in bovine adrenal chromaffin cells, J. Neurochem. 107 (2008) 658-667.

[167] T. Iwamoto, T. Watano, M. Shigekawa, A novel isothiourea derivative selectively inhibits the reverse mode of $\mathrm{Na}^{+} / \mathrm{Ca}^{2+}$ exchange in cells expressing NCX1, J. Biol. Chem. 271 (1996) 22391-22397.
[168] J. Santo-Domingo, L. Vay, E. Hernandez-Sanmiguel, C.D. Lobaton, A. Moreno, M. Montero, J. Alvarez, The plasma membrane $\mathrm{Na}^{+} / \mathrm{Ca}^{2+}$ exchange inhibitor KB-R7943 is also a potent inhibitor of the mitochondrial $\mathrm{Ca}^{2+}$ uniporter, $\mathrm{Br}$. J. Pharmacol. 151 (2007) 647-654.

[169] A.J. Pintado, C.J. Herrero, A.G. Garcia, C. Montiel, The novel $\mathrm{Na}(+) / \mathrm{Ca}(2+)$ exchange inhibitor KB-R7943 also blocks native and expressed neuronal nicotinic receptors, Br. J. Pharmacol. 130 (2000) 1893-1902.

[170] T. Iwamoto, Y.Watanabe, S. Kita, M.P. Blaustein, $\mathrm{Na}^{+} / \mathrm{Ca}^{2+}$ exchange inhibitors: a new class of calcium regulators, Cardiovasc. Hematol. Disord. Drug Targets 7 (2007) 188-198.

[171] S. Soma, H. Kuwashima, C. Matsumura, T. Kimura, Inhibition by SEA0400, a selective inhibitor of $\mathrm{Na}^{+} / \mathrm{Ca}^{2+}$ exchanger, of $\mathrm{Na}^{+}$-dependent $\mathrm{Ca}^{2+}$ uptake and catecholamine release in bovine adrenal chromaffin cells, J. Pharmacol. Sci. 102 (2006) 88-95.

[172] M.J. Berridge, Calcium microdomains: organization and function, Cell Calcium 40 (2006) 405-412.

[173] C. Viero, G. Dayanithi, Decoding calcium signals in living cells, IIOAB J. 1 (2010) $11-16$.

[174] V. De Crescenzo, R. ZhuGe, C. Velazquez-Marrero, L.M. Lifshitz, E. Custer, J. Carmichael, F.A. Lai, R.A. Tuft, K.E. Fogarty, J.R. Lemos, J.V. Walsh Jr., $\mathrm{Ca}^{2+}$ syntillas, miniature $\mathrm{Ca}^{2+}$ release events in terminals of hypothalamic neurons, are increased in frequency by depolarization in the absence of $\mathrm{Ca}^{2+}$ influx, $\mathrm{J}$. Neurosci. 24 (2004) 1226-1235.

[175] R. ZhuGe, V. DeCrescenzo, V. Sorrentino, F.A. Lai, R.A. Tuft, L.M. Lifshitz, J.R. Lemos, C. Smith, K.E. Fogarty, J.V. Walsh Jr., Syntillas release $\mathrm{Ca}^{2+}$ at a site different from the microdomain where exocytosis occurs in mouse chromaffin cells, Biophys. J. 90 (2006) 2027-2037.

[176] J.J. Lefkowitz, K.E. Fogarty, L.M. Lifshitz, K.D. Bellve, R.A. Tuft, R. ZhuGe, J.V. Walsh Jr., V. De Crescenzo, Suppression of $\mathrm{Ca}^{2+}$ syntillas increases spontaneous exocytosis in mouse adrenal chromaffin cells, J. Gen. Physiol. 134(2009) 267-280.

[177] J.C. Fernandez-Morales, M. Yanez, F. Orallo, L. Cortes, J.C. Gonzalez, J.M. Hernandez-Guijo, A.G. Garcia, A.M. de Diego, Blockade by nanomolar resveratrol of quantal catecholamine release in chromaffin cells, Mol. Pharmacol. 78 (2010) 734-744.

[178] N. Sasaki, G. Dayanithi, I. Shibuya, $\mathrm{Ca}^{2+}$ clearance mechanisms in neurohypophysial terminals of the rat, Cell Calcium 37 (2005) 45-56.

[179] Y. Komori, M. Tanaka, M. Kuba, M. Ishii, M. Abe, N. Kitamura, A. Verkhratsky, I. Shibuya, G. Dayanithi, $\mathrm{Ca}(2+)$ homeostasis, $\mathrm{Ca}(2+)$ signalling and somatodendritic vasopressin release in adult rat supraoptic nucleus neurones, Cell Calcium 48 (2010) 324-332.

[180] Z. Zhou, E. Neher, Mobile and immobile calcium buffers in bovine adrenal chromaffin cells, J. Physiol. 469 (1993) 245-273.

[181] C.R. Artalejo, A.G. Garcia, D. Aunis, Chromaffin cell calcium channel kinetics measured isotopically through fast calcium, strontium, and barium fluxes, J. Biol. Chem. 262 (1987) 915-926.

[182] E. Neher, G.J. Augustine, Calcium gradients and buffers in bovine chromaffin cells, J. Physiol. 450 (1992) 273-301.

[183] E. Neher, Usefulness and limitations of linear approximations to the understanding of $\mathrm{Ca}^{++}$signals, Cell Calcium 24 (1998) 345-357.

[184] A. Hernandez-Cruz, F. Sala, P.R. Adams, Subcellular calcium transients visualized by confocal microscopy in a voltage-clamped vertebrate neuron, Science 247 (1990) 858-862.

[185] M.T. Alonso, P. Chamero, C. Villalobos, J. Garcia-Sancho, Fura-2 antagonises calcium-induced calcium release, Cell Calcium 33 (2003) 27-35.

[186] M.C. Nowycky, M.J. Pinter, Time courses of calcium and calcium-bound buffers following calcium influx in a model cell, Biophys. J. 64 (1993) 77-91.

[187] J. Herrington, Y.B. Park, D.F. Babcock, B. Hille, Dominant role of mitochondria in clearance of large $\mathrm{Ca}^{2+}$ loads from rat adrenal chromaffin cells, Neuron 16 (1996) 219-228

[188] G. Uceda, A.G. Garcia, J.M. Guantes, P. Michelena, C. Montiel, Effects of $\mathrm{Ca}^{2+}$ channel antagonist subtypes on mitochondrial $\mathrm{Ca}^{2+}$ transport, Eur. J. Pharmacol. 289 (1995) 73-80.

[189] R.H. Chow, J. Klingauf, E. Neher, Time course of $\mathrm{Ca}^{2+}$ concentration triggering exocytosis in neuroendocrine cells, Proc. Natl. Acad. Sci. U.S.A. 91 (1994) 12765-12769.

[190] P. Michelena, T. Vega, C. Montiel, M.G. Lopez, L.E. Garcia-Perez, L. Gandia, A.G. Garc-ia, Effects of tyramine and calcium on the kinetics of secretion in intact and electroporated chromaffin cells superfused at high speed, Pflugers Arch. 431 (1995) 283-296.

[191] J. Klingauf, E. Neher, Modeling buffered $\mathrm{Ca}^{2+}$ diffusion near the membrane: implications for secretion in neuroendocrine cells, Biophys. J. 72 (1997) 674-690.

[192] Z. Zhou, S. Misler, Action potential-induced quantal secretion of catecholamines from rat adrenal chromaffin cells, J. Biol. Chem. 270 (1995) 3498-3505.

[193] L. Olivos Ore, A.R. Artalejo, Intracellular $\mathrm{Ca}^{2+}$ microdomain-triggered exocytosis in neuroendocrine cells, Trends Neurosci. 27 (2004) 113-115.

[194] U. Becherer, T. Moser, W. Stuhmer, M. Oheim, Calcium regulates exocytosis at the level of single vesicles, Nat. Neurosci. 6 (2003) 846-853.

[195] C. Villalobos, L. Nunez, P. Chamero, M.T. Alonso, J. Garcia-Sancho, Mitochondrial $[\mathrm{Ca}(2+)]$ oscillations driven by local high $[\mathrm{Ca}(2+)]$ domains generated by spontaneous electric activity, J. Biol. Chem. 276 (2001) 40293-40297.

[196] C. Heinemann, L. von Ruden, R.H. Chow, E. Neher, A two-step model of secretion control in neuroendocrine cells, Pflugers Arch. 424 (1993) 105-112. 
[197] K.L. Engisch, N.I. Chernevskaya, M.C. Nowycky, Short-term changes in the $\mathrm{Ca}^{2+}$-exocytosis relationship during repetitive pulse protocols in bovine adrenal chromaffin cells, J. Neurosci. 17 (1997) 9010-9025.

[198] K.L. Engisch, M.C. Nowycky, Calcium dependence of large dense-cored vesicle exocytosis evoked by calcium influx in bovine adrenal chromaffin cells, J. Neurosci. 16 (1996) 1359-1369.

[199] R. Thiagarajan, J. Wilhelm, T. Tewolde, Y. Li, M.M. Rich, K.L. Engisch, Enhancement of asynchronous and train-evoked exocytosis in bovine adrenal chromaffin cells infected with a replication deficient adenovirus, J. Neurophysiol. 94 (2005) 3278-3291.

[200] V. Carabelli, A. Giancippoli, P. Baldelli, E. Carbone, A.R. Artalejo, Distinct potentiation of L-type currents and secretion by cAMP in rat chromaffin cells Biophys. J. 85 (2003) 1326-1337.

[201] E. Neher, R.S. Zucker, Multiple calcium-dependent processes related to secretion in bovine chromaffin cells, Neuron 10 (1993) 21-30.

[202] M.L. Vitale, E.P. Seward, J.M. Trifaro, Chromaffin cell cortical actin network dynamics control the size of the release-ready vesicle pool and the initial rate of exocytosis, Neuron 14 (1995) 353-363.

[203] T. Voets, T. Moser, P.E. Lund, R.H. Chow, M. Geppert, T.C. Sudhof, E. Neher, Intracellular calcium dependence of large dense-core vesicle exocytosis in the absence of synaptotagmin I, Proc. Natl. Acad. Sci. U.S.A. 98 (2001) 11680-11685.

[204] S.A. Chan, C. Smith, Physiological stimuli evoke two forms of endocytosis in bovine chromaffin cells, J. Physiol. 537 (2001) 871-885.

[205] A.M. de Diego, J.J. Arnaiz-Cot, J.M. Hernandez-Guijo, L. Gandia, A.G. Garcia, Differential variations in $\mathrm{Ca}^{2+}$ entry, cytosolic $\mathrm{Ca}^{2+}$ and membrane capacitance upon steady or action potential depolarizing stimulation of bovine chromaffin cells, Acta Physiol. (Oxf.) 194 (2008) 97-109.

[206] K.L. Engisch, M.C. Nowycky, Compensatory and excess retrieval: two types of endocytosis following single step depolarizations in bovine adrenal chromaffin cells, J. Physiol. 506 (Pt 3) (1998) 591-608.

[207] P.G. Nucifora, A.P. Fox, Barium triggers rapid endocytosis in calf adrenal chromaffin cells, J. Physiol. 508 (Pt 2) (1998) 483-494.
[208] C.R. Artalejo, J.R. Henley, M.A. McNiven, H.C. Palfrey, Rapid endocytosis coupled to exocytosis in adrenal chromaffin cells involves $\mathrm{Ca}^{2+}, \mathrm{GTP}$, and dynamin but not clathrin, Proc. Natl. Acad. Sci. U.S.A. 92 (1995) 8328-8332.

[209] J.M. Rosa, L. Gandia, A.G. Garcia, Permissive role of sphingosine on calciumdependent endocytosis in chromaffin cells, Pflugers Arch. 460 (2010) 901-914.

[210] J.M. Rosa, A.M. de Diego, L. Gandia, A.G. Garcia, L-type calcium channels are preferentially coupled to endocytosis in bovine chromaffin cells, Biochem. Biophys. Res. Commun. 357 (2007) 834-839.

[211] J.M. Rosa, C.J. Torregrosa-Hetland, I. Colmena, L.M. Gutierrez, A.G. Garcia, L. Gandia, Calcium entry through slow-inactivating L-type calcium channels preferentially triggers endocytosis rather than exocytosis in bovine chromaffin cells, Am. J. Physiol. Cell Physiol. 301 (2011) C86-C98.

[212] M. Villarroya, R. Olivares, A. Ruiz, M.F. Cano-Abad, R de Pascual, R.B. Lomax, M.G. Lopez, I. Mayorgas, L. Gandia, A.G. Garcia, Voltage inactivation of $\mathrm{Ca}^{2+}$ entry and secretion associated with $\mathrm{N}$ - and P/Q-type but not L-type $\mathrm{Ca}^{2+}$ channels of bovine chromaffin cells, J. Physiol. 516 (Pt 2) (1999) 421-432.

[213] M.J. Berridge, Calcium hypothesis of Alzheimer's disease, Pflugers Arch. 459 (2010) 441-449.

[214] U. Dreses-Werringloer, J.C. Lambert, V. Vingtdeux, H. Zhao, H. Vais, A. Siebert A. Jain, J. Koppel, A. Rovelet-Lecrux, D. Hannequin, F. Pasquier, D. Galimberti, E. Scarpini, D. Mann, C. Lendon, D. Campion, P. Amouyel, P. Davies, J.K. Foskett, F. Campagne, P. Marambaud, A polymorphism in CALHM1 influences $\mathrm{Ca}^{2+}$ homeostasis, Abeta levels, and Alzheimer's disease risk, Cell 133 (2008) 1149-1161.

[215] A.J. Moreno-Ortega, A. Ruiz-Nuno, A.G. Garcia, M.F. Cano-Abad, Mitochondria sense with different kinetics the calcium entering into HeLa cells through calcium channels CALHM1 and mutated P86L-CALHM1, Biochem. Biophys. Res. Commun. 391 (2010) 722-726.

[216] J.M. Wang, C. Sun, Calcium and neurogenesis in Alzheimer's disease, Front Neurosci. 4 (2010) 194. 